\title{
AKAR TRADISI TOLERANSI DI INDONESIA DALAM PERSPEKTIF PERADABAN ISLAM ${ }^{1}$
}

\author{
Kusmana \\ UIN Syarif Hidayatullah Jakarta
}

\begin{abstract}
This paper delves chronologically the root of Indonesian Muslims' tolerance tradition in the history of Islamic civilization starting from the period of caliphate to the modern one to cherish this tradition in the country. Here, this study uses a descriptive and analytical method to problematize how Muslims in Indonesia gratify themselves with the tradition of tolerance from the Islamic civilization history they read to resolve intolerance that has recently emerged. This study uncovers that Muslims in Indonesia have actually learned that the Islamic civilization history depicts the tolerance tradition concepts prior to this convention in the West. This paper argues that this understanding is potential to be a social capital for Muslims in Indonesia to cultivate the tolerance tradition in the country; thereby being able to perpetuate Islam as the religion of 'blessing for all universe' (rahmatan li-al'alamin).
\end{abstract}

Keywords: Tolerance, Islamic civilization, Indonesia, social capital, and symbolic role.

\section{A. Pengantar}

Sumber nilai dan praktek sosial toleransi di Indonesia salah satunya mengakar dari peradaban agama Islam yang datang ke kepulauan Nusantara lebih dari 8 abad yang lalu dengan cara damai. Seperti dalam peradaban agama lain, peradaban Islam juga mempunyai pengalaman mengenai toleransi dengan keragaman pengalamannya sendiri. Mendiskusikan pengalaman toleransi tidak berarti ummat beragama, termasuk ummat Islam, tidak mempunyai pengalaman intoleransi. Toleransi dan intolerasi terjadi dalam sejarah ummat beragama bahkan ummat manusia secara umum. Dengan kata lain keduanya merupakan bagian dari sejarah manusia.

${ }^{1}$ Sebagian besar dari makalah ini merupakan kontribusi tulisan untuk modul berjudul "Modul Dakwah Islam Rahmatan Lil 'Alamin, Pegangan bagi para Da'i dan Dewan Kemakmuran Masjid," tahun 2012. Makalah ini ditulis-ulang dalam kontek toleransi di Indonesia dan diterbitkan karena kandungannya yang dianggap penting dan relevan, dan untuk menjangkau pembaca yang lebih luas. Penulis dapat di kontak di kusmana@uinjkt.ac.id 
Kemunculannya dipengaruhi oleh sejumlah faktor mulai dari faktor alam dan waktu, sampai faktor ideologi, ekonomi, sosial, budaya, dan politik.

Toleransi sebenarnya terma yang problematis, karena seringnya proses relasi subjek dan obyek yang timpang, dimana aktualisasi toleransi lebih banyak ditentukan oleh subjek. Muatan makna toleransi karena itu mesti didudukkan terlebih dahulu untuk mengantisipasi ketimpangan tersebut. Muatan nilai seperti mutual respect (saling menghormati), peaceful attitude (sikap damai atau salam atau silm), keadilan dan kesetaraan adalah ramuan dasar dan ideal. Prinsip-prinsip tersebut menjadi tolok ukur praktek toleransi. Al-Qur' an dan Sunnah Rasul sangat menekankan prinsip-prinsip tersebut dan menjadi ciri pokok ekspresi Islam sebagai agama rahmat bagi keseluruhan alam (rahmatan li al-'alamin). Penghormatan keberadaan yang lain seperti yang ditegaskan dalam al-Qur'an 109/al-Kafirun: 6 "untukmulah agamamu dan untukulah agamaku," dan penghormatan akan perbedaan pendapat seperti ditegaskan Rasul "perbedaan pendapat diantara ulama adalah karunia dari Allah," sangat ditekankan dalam Islam. Al-Qur'an sendiri menghormati keragaman ummat manusia sebagai salah satu fitrah realitas eksistensi manusia dan menegaskan kemulian manusia tergantung ketakwaannya seperti yang tercantum dalam QS al-Hujurat/49: 13. Merujuk pada ayat tersebut Nabi Muhammad menegaskan bahwa "sesungguhnya bangsa Arab tidak lebih utama dari pada bangsa bukan Arab, orang kulit putih tidak lebih mulia dari pada orang kulit hitam, tidak juga sebaliknya. Keutamaan dan kemuliaan seseorang tergantung pada takwanya." (Riwayat dikutip dari Hadits al-'Ida bin Khalid dalam Kitab al-Mu'jam al-Kabir karangan athThabrani) $)^{2}$ Dengan kata lain, rumusan ideal toleransi telah diletakkan dasardasarnya di zaman Nabi baik melalui firman Allah maupun dicontohkan dalam Sunnah Rasul, Muhammad, dengan menjunjung nilai hak eksistensi, kebebasan berpendapat, keadilan dan kesetaraan. Peradaban Islam dalam perkembangan sejarah teraktualisasi dalam perbedaan waktu dan tempat. Keduanya mempengaruhi corak dan muatan toleransi itu sendiri. Semua pengalaman-pengalaman tersebut memperkaya dimensi-dimensi praktek toleransi, mulai dari praktek toleransi yang paling tulus sampai yang bernuansa sosial politis.

${ }^{2}$ Muhammad Rasyid Ridha. 1987. Cet ke 2. Wahyu Ilahi Kepada Muhammad. Jakarta: Pustaka Jaya. Pp. 427-8.

2 | INDO-ISLAMIKA, Volume 7 No.1 Januari-Juni 2017/1438 
Peradaban Islam terbentuk sampai saat ini lebih dari empat belas abad, mulai dari zaman Rasul (sampai 11H/632 M), Khulafa al-Rasydin (11 H/632 M - 40 H/661 M), Bani Umayyah (40 H/661 M - 132 H/750 M), Khilafah Abbasiyah (132 H/750 M - 656 H/1258 M), Saffariyyah (867-908 M), Samaniyah (879-999 M), Dinasti Seljuk (426 H/1035 M- 656 H/1258 M), Daulah Fatimiyah (abab ke 4 H/abad ke 10 M - 583 H/1187 M), Dinasti Bani Umayyah di Spanyol (138 H/756 M - 897 H/1492 M), Dinasti Ilkhan (1258 M - 1500 M), Kerajaan Turki Ustmani (726 H/1326 M - abad ke 13 M/awal Abad 20 M), Kerajaan Safawi di Persia (905 H/1499 M - 1343 H/1924 M), Kerajaan Mughal di India (932 H/1526M - 1274 H/1858 M), dan kerajaankerajaan Islam kecil lain: Sub Sahara Afrika, Asia Tenggara termasuk Indonesia, Cina dan Islam di daerah-daerah geografi bangsa Barat, serta Islam di masa kemunduran politik dan zaman modern. Pada tahun 1998 muslim merupakan $20 \%$ penduduk dunia, yaitu 1,2 milyar tersebar di seluruh Dunia. 800 juta Muslim dari jumlah tersebut tinggal di 45 negara berpenduduk mayoritas Muslim. Selebihnya, 400 juta jiwa tinggal sebagai minoritas di 149 negara. $^{3}$

Ummat Islam di Nusantara dan sekarang negara Republik Indonesia sebagai penduduk mayoritas tentunya menjadi agensi penting yang memupuk nilai dan tradisi toleransi di negeri ini. Tulisan ini mencoba melacak sumber nilai dan praktek sosial toleransi dalam peradaban Islam. Hal ini penting untuk diinformasikan untuk mengetahui runtutan sumber dan preseden yang mengakaitkan praktek toleransi di negeri ini dengan praktekpraktek toleransi di negeri Muslim lain dalam lintasan sejarah. Selain itu, identifikasi ini juga penting untuk menambah gambaran yang lebih komprehensif tentang praktek toleransi dalam Islam sebagai tambahan dan perbandingan informasi alternatif.

\section{Toleransi dalam Lintasan Peradaban Islam}

Sejak kemunculannya lebih dari empat belas abad lalu hingga saat ini ummat Islam tidak dapat dipungkiri telah berkontribusi penting terhadap perkembangan peradaban ummat manusia secara keseluruhan. Salah satu kontribusi penting tersebut adalah dalam hal tolerasi. Dari kemunculannya, ummat Islam dapat berbangga dengan kenyataan bahwa agama Islam baik

${ }^{3}$ Riaz Hasan. 2006. Keragaman Iman: Studi Komparatif Masyarakat Muslim. Jakarta: PT. RajaGrafindo Persada, P. 1.

INDO-ISLAMIKA, Volume 7 No.1 Januari-Juni 2017/1438 | 3 
secara preskripsi atau praktek sangat memperhatikan persoalan toleransi. Kekuatan toleransi Islam pada masa awal ditunjukkan dengan pemberian perlindungan hak yang sama dengan ummat Islam kepada ummat lain yang ditaklukan. Memang ada konsep Kafir dan dhimmi, tapi kedua konsep tersebut dalam kehidupan bermasyarakat sehari-hari didudukan pada konsep hidup saling berdampingan dan saling menghormati. Islam menyeru mereka untuk masuk Islam tapi sebatas seruan, keputasan berada pada mereka yang diseru. Tidak ada paksaan dalam beragama, sebagaimana diisyaratkan dengan tegas dalam Q.S. 109: 6. Lebih lanjut, bukan hanya orang tua, perempuan dan anak-anak yang perlu dilindungi, tapi mereka semua yang telah menerima kekuasaan Islam mendapat perhatian yang besar. Toleransi tersebut diiringi dengan sikap terbuka terhadap ilmu pengetahuan dan keterampilan. Sudah menjadi rahasia umum, penguasa Muslim meminta kepada mereka yang mempunyai ilmu pengetahuan dan keterampilan untuk berbagi kepada ummat Islam. Sikap memberi penghormatan pada ilmu pengetahuan dan keterampilan yang ditunjukkan ummat Islam merupakan sikap mulia dan maju yang mendukung kemajuan peradaban ummat manusia. Secara internal, sikap terbuka terhadap perbedaan wacana ditunjukkan oleh para ulama, baik dibidang teologi, hukum maupun pemikiran sufistik dan filsafat.

Kenyataan lain dari peradaban ummat Islam adalah beragamnya bentuk pemerintahan, mulai dari kekhalifahan, kerajaan, kesultanan sampai bentuk sistem pemerintahan modern sekarang baik itu yang bersifat teokrasi sampai demokrasi. Terlepas dari wacana pro dan kontra bentuk-bentuk pemerintahan yang ideal, tapi ummat Islam mempunyai pengalaman berbagai bentuk pemerintahan. Ada satu argumentasi yang sering digunakan untuk mentoleransi berbagai bentuk system negara, yaitu ummat Islam lebih memilih untuk dipimpin oleh pimpinan yang adil dari pada dipimpin oleh seorang Muslim yang dhalim atau dari pada tidak ada pemimpin sama sekali. Walau hal ini sering digunakan sebagai alasan penerimaan keadaan sementara, sikap sebenarnya sebagian ummat Islam menolak terhadap system pemerintahan yang ada. Secara sosiologis praktek tersebut merupakan bentuk toleransi yang memungkin koeksistensi secara damai dan saling menghormati ummat Islam.

Masyarakat Arab sebagai penganut Islam awal adalah bagian dari masyarakat Timur Tengah. Peradaban Arab dengan demikian merupakan 
bagian dari peradaban Timur Tengah. Walau Islam datang dengan sejumlah perbaikan dan konsep baru, pada dasarnya masyarakat muslim awal mewarisi peradaban masyarakat Timur Tengah. Dengan kata lain, kelembagaan masyarakat Arab pra Islam membentuk peradaban awal itu sendiri dan bersama dengan penerimaan dan perbaikan Islam terhadap tradisi masa lalu dan pengenalan hal baru dari Islam, kesemuanya ikut membentuk peradaban Islam secara umum dan peradaban Islam masa depan. Kelembagaan-kelembagaan tersebut antara lain adalah masyarakat kecil yang di dasarkan pada keluarga, garis keturunan, ikatan klien dan etnik, masyarakat pertanian dan kota, ekonomi pasar, agama monotheis, dan birokrasi imperium. Kesemua elemen konstruksi peradaban tersebut berakar dari masyarakat Palestina, Babylon dan Persepolis. Karena peradaban Islam yang terlahir di Mekkah tidak terlepas dari pengaruh peradaban yang mendahuluinya dan mengitarinya, termasuk tiga peradaban yang ada. ${ }^{4}$

Peradaban yang ada dapat dicirikan oleh setidaknya dua hal. Pertama, pengorganisasian masyarakat ke dalam kelompok-lelompok kecil, bahkan kelompok-kelompok berdasarkan keluarga. Dalam keorganisasin masyarakat seperti itu, kehidupan masyarakat berevolusi dari kehidupan yang bercirikan kehidupan masyarakat dalam kelompok kecil dan mempertahankan hidup dari alam seperti bertani atau berburu, sampai berdagang. Struktur kemasyarakatan mereka diikat oleh kekerabatan dan rukun tetangga dimana rasa cinta dan benci yang kuat menjadi nuansa yang memberi warna dinamika kehidupannya. Ciri umum dari masyarakat demikian adalah memperhatikan kehidupan generasi muda, mempunyai kebiasan perkawinan yang diatur, penyelesain konflik dengan arbitrase, dan membentuk masyarakat dengan pola membedakan dengan pihak di luar mereka. ${ }^{5}$

Kedua, kehadiran peradaban Islam didahului dengan peradaban sebelumnya. Kehadiran peradaban Islam secara evolutif berpengaruh pada melemahnya peradaban yang ada dan terciptanya peradaban yang berkencenderungan menyatukan budaya, agama dan imperium dalam skala yang besar. Di zaman pra sejarah,misalnya, peradaban Mesopotamia (3500 2400 SM) mengalami pelemahan secara gradual misalnya sejak 2400 SM telah mulai muncul lembaga-lembaga penyatu yang baru. Kekerabatan dan imperium menjadi faktor penting terhadap muncul dan tenggelamnya

\footnotetext{
${ }^{4}$ Ira M. Lapidus. 1988. A History of Islamic Society. Cambridge: Cambridge University Press, p. 3

${ }^{5}$ Lapidus. 1988. A History of Islamic Society. P. 3
}

INDO-ISLAMIKA, Volume 7 No.1 Januari-Juni 2017/1438 | 5 
imperium besar yang menyatukan keragaman yang ada, seperti imperium Sargon dan Hammurabi (antara 2400 SM - 1750 SM). Seiring datang dan perginya imperium atau kekuasan politik, elaborasi dan perluasan kelembagaan baru dalam kehidupan masyarakat berkembang. Warisan kelembagaan-kelembagaan tersebut seperti pergerakan prajurit, interaksi admnistrator, pedagang, tokoh agama, sarjana dan pekerja merupakan warisan budaya kosmopolitan dan warisan bersama tentang hukum, bahasa, dokumen dan identitas sosial. ${ }^{6}$

Perkembangan selanjutnya setelah munculnya Sargon dan Hammurai sebagai bagian dari sejarah imperium Mesopotamia adalah kemunculan imperium-imperium lainnya, seperti Hittite, Kassite dan lainnya. Kesemuanya membawa Mesopotamia, Anatolia dan Iran dalam jaringan imperium baru. Kemudian imperium Assyiria (911 SM - 612 SM) membawa Irak, Iran bagian Barat, dan dalam kurun tertentu Mesir ke dalam satu pemerintahan. Imperium Acheminid (550 SM - 331 SM) berhasil memasukkan bagian Selatan Iran dan membentuk Imperium Timur Tengah yang di dalamnya tergabung masyarakat dari sungai oxus dan Nil serta Dardanelles. Runtuhnya Imperium Achaminid oleh Alexander Yang Agung, Timur Tengah terbagi dalam dua imperium: Imperium Persia dan penerusnya (226 SM-234 M) dan Imperium Sasanian (234 M-634 M). Di Barat, daerah penerus Alexander Yang Agung menjadi bagian dari Imperium Roman. Imperium Roman akhir, disebut Imperium Byzantine memerintah Eropa bagian Selatan, daerah Balkan, Anatolia, Syiria bagian Utara, dan sebagian dari wilayah Mesopotamia, Mesir, dan Afrika Utara. ${ }^{7}$

Selain peradaban Islam di dahului dengan perkembangan masyarakat yang keberhasilannya sampai pada pembentukan imperium, perkembangan agama yang mengiringi perkembangan peradaban manusia yang awalnya diwarnai dengan penyembahan Tuhan yang didasarkan alam dan tempat ke arah peyembahan Tuhan yang Satu. Penyembahan Tuhan yang satu menjadi lebih besar setelah interaksi sosial terjadi intensifikasi manakala corak tata kelola semakin komplek, besar dan luas dalam bentuk imperium. Kehadiran Islam yang menyembah Tuhan yang Satu didahului kehadiran Tuhan yang satu yang dianut oleh Yahudi, Zoroaster dan Kristiani. Lapidus menjelaskan lebih lanjut bahwa ketiga agama tersebut mempunyai ciri umum sebagai

\footnotetext{
${ }^{6}$ Lapidus. 1988. A History of Islamic Society. Pp. 3-6

${ }^{7}$ Lapidus. 1988. A History of Islamic Society. P. 6
} 
agama yang transendental, yang menghubungkan keimanan dengan kehidupan di dunia. Ketiganya mempunyai klaim pesan universal. Pengikutnya disatukan dalam persaudaraan seiman, mencari keselamatan di dunia dan akhirat.

Walaupun berbeda orientasi, Yudaisme, Zorostianisme dan Kristianitas mempunyai karakter dasar yang sama. Semuanya bersifat agama transendental. Semuanya berpegang bahwa di luar dari kehidupan ini, ada dunia yang lebih tinggi, realitas ketuhanan, yang dikaitkan melalui tindakan ethis penganutnya atau melalui keimanan terhadap Tuhan. Melalui pengorbanan (qurban), do'a (sholat), sacrament (perbaikan diri), mereka mencari pengampunan dosa, keselamatan setelah kematian, dan masuk bagi manusia ke dalam realitas di luar realitas kehidupan dunia yang singkat. Lebih jauh, agama-agama tersebut memiliki klaim agama universal, mempercayai bahwa Tuhan telah menciptakan dan terus mengatur alam raya dan manusia. Di depan Tuhan, penganut agama, secara individu bertanggungjawab atas keimanan dan karakter etis mereka. Mereka adalah saudara dalam agama dan pencarian jalan keselamatan. ${ }^{8}$

Sebelum kehadiran peradaban Islam, peradaban sebelumnya khususnya yang terbangun dari pengaruh tiga agama besar -Yahudi, Zoroaster dan Kristen- menginformasikan model-model praktek pengorganisasian hidup bermasyarakat dan bernegera yang mengkaitkan aspek spiritual dan sosial. Eksistensi mereka juga menjadi prakondisi penyembahan Tuhan yang Esa, minimal, Tuhan yang mendapat dukungan imperium. Selanjutnya, timbul dan tenggelamnya kekuasaan poltik yang bercirikan kekerabatan dan imperium dimana agama juga ikut berkembang di dalamnya mempengaruhi imajinasi sosial masyarakat setelahnya termasuk imajinasi masyarakat Muslim.

Tidak heran kemudian kontek peradaban sebelum kehadiran Islam didahului dengan dua kenyataan politik dan budaya -Byzantium dan Sasania, dan dua ruang tumpang tindih keyakinan antara Kristen dan Zoroaster. Terlepas dari perbedaan yang ada, dua peradaban Timur Tengah mempunyai kemiripan tertentu dalam organisasi imperium, kepercayaan keagamaan, dan struktur kehidupan komunal dan keagamaan. Antara agama dan negara berinteraksi secara dekat. Secara eksternal, fakta sejarah menunjukkan peradaban Sasanian agak lebih toleran dengan Byzantium. Hal ini terlihat

${ }^{8}$ Lapidus. 1988. A History of Islamic Society. P. 8

INDO-ISLAMIKA, Volume 7 No.1 Januari-Juni 2017/1438 | 7 
dari organisasi gereja Byzantium yang sistematis tapi kaku , dibanding dengan organisasi melalui kepemimpinan Mobad dalam tradisi Zoroaster imperium Sasanian. ${ }^{9}$

Perkembangan selanjutnya konteks peradaban Islam mengalami perubahan. Dalam perkembangan selanjutnya, sebelum zaman modern (1200 - 1800), peradaban Islam ditandai dengan penaklukan yang dilakukan masyarakat tribal, pedagang pelancong, para sufi membawa Islam keluar Timur Tengah, sampai ke Asia Dalam, India, Asia Tenggara, Turkey, wilayah Balkan, Afrika Utara dan Barat dan daerah lainnya seperti Cina. Seperti di Timur Tengah, prinsip unversal Islam bersinergi dengan tradisi dan kearifan lokal. Menjelang abad ke 17, masyarakat Islam dapat ditemukan di Asia, Afrika, Eropa Timur. ${ }^{10}$

Berbeda dari peradaban Islam sebelumnya yang banyak berperan sebagai pihak penguasa, peradaban Islam modern (1800 - sekarang) selain terus memelihara peradaban sebelumnya, mengalami situasi baru dimana faktor ekternal masuk ke dalam peradaban Islam dalam posisi pada umumnya masyarakat Islam ada dalam pengaruh kekuatan eksternal, khususnya kekuatan imperialisme dan kolonialsime. Sampai pertengahan abad dua puluhan, banyak masyarakat Islam terjajah oleh kekuatan Barat. Peradaban Barat tampil menjadi kekuatan sangat berpengaruh sampai sekarang. Masyarakat Muslim sebelum atau sesudah kemerdekaan tidak lepas dari pengaruh peradaban Barat. Negara Turki yang tidak sempat dijajah oleh negara Barat, sejak tahun 1924 mengambil kebijakan modernisasi negara ala Barat dengan penerapakan kebijakan sekularisasinya. Sebagaimana masyarakat beragama lainnya, masyarakat muslim yang memiliki pengaruh besar dalam negara, dengan variasinya sendiri banyak menerima pengaruh Barat baik sistem politik, isu HAM dan jender maupun dalam hal ilmu pengetahuan dan teknologi.

Paska imperialisme dan kolonialisme, masyarakat Muslim tersebar di seluruh dunia sebagai penduduk mayoritas atau minoritas. Baik sebagai masyarakat mayoritas maupun minoritas, Masyarakat Muslim berhubungan dengan masyarakat agama lainnya seperti Kristen, Yahudi, Budha, dan Hindu. Situasi mereka sebagai mayoritas berbeda dengan mereka sebagai minoritas. Peradaban Islam dalam fase ini mentransformasikan situasi yang

\footnotetext{
${ }^{9}$ Lapidus. 1988. A History of Islamic Society. P. 9

${ }^{10}$ Lapidus. 1988. A History of Islamic Society. P. 880
}

8 | INDO-ISLAMIKA, Volume 7 No.1 Januari-Juni 2017/1438 
ada ke dalam peradaban mereka. Keragaman peradaban Islam sekarang dikonstruksi dalam konteks negara modern dengan sistem politik modern juga. Tradisi, budaya dan sistem politik lama seperti kerajaan diadaptasi ke dalam sistem negara modern. Kekuatan di dalam suatu negara berkembang tidak hanya negara dengan segala perangkatnya tapi unsur masyarakat seperti organisasi masyarakat, lembaga swadaya masyarakat atau kaum intelegensia. Kekuatan di luar negara menjadi masyarakat-masyarakat madani (civil society) yang menjadi kekuatan penyeimbang atau kontrol bagi tata kelola negara.

\section{Konstruksi Peradaban}

Kehadiran Islam, lebih dari 1400 tahun lalu mengkonstruksi peradaban baru di atas peradaban sebelumnya. Nabi Muhammad sebagai utusan Allah dengan bimbingan wahyu memberi makna baru terhadap peradaban yang ada melalui tiga strategi efektifnya: penerimaan, pelanjutan dan perbaikan keagamaan yang ada. Islam hadir dengan semangat menerima tradisi keagamaan yang ada sepanjang sesuai dengan ajaran pokok Islam, melanjutkan sebagian tradisi keagamaan yang ada dan mengoreksinya agar sesuai dengan semangat Islam. Dalam bahasa Seyyed Hossein Nasr Islam hadir untuk menegaskan kembali kebenaran yang telah ada sejak dulu. Sebagai ajaran agama yang sesuai dengan fitrah dan rahmat bagi alam semesta, Islam menekan ajarannya pada esensi, universalitas, kesederhanaan, dan bersikap inklusif terhadap ajaran agama dan kebijaksanaan yang datang sebelumnya. ${ }^{11}$

Lapidus menjelaskan bahwa hampir 5000 tahun Timur Tengah dan masyarakat Islam mendasarkan eksistensi mereka pada konstelasi garis keturunan, kesukuan, agama, kelembagaan politik. Konfigurasi kelembagankelembagan tersebut merupakan dasar dari masyarakat pra-Islam Timur Tengah dan model di atas mana peradaban masyarakat Islam dikonstruksi. Awal peradaban Islam terlembagakan dalam kesukuan Arab dan dalam tradisi lainnya mengikuti penyebaran Islam itu sendiri dalam lintasan sejarahnya. Penaklukan Muslim terhadap Timur Tengah memberi pengalaman konstruksi peradaban kenegaraan Islam bercorak kekhalifahan dan kesultanan dan konstruksi peradaban masyarakat Islam yang bercirikan

\footnotetext{
${ }^{11}$ Sayyed Hossein Nasr. 2003. Islam: Agama, Sejarah, dan Peradaban. Surabaya. Risalah Gusti, p. 6.
} 
madhab hukum Islam (dengan mayoritas fiqh Sunni), persaudaraan sufi, dan Islam Shi'ah. Proses semua kelembagaan tersebut medorong lahirnya peradaban baru, peradaban Islam. ${ }^{12}$

Selanjutnya Lapidus menjelaskan bahwa peradaban Islam tidak lepas dari pengaruh dua wilayah keagamaan dan politik dengan bentuk-bentuk kelembagaan yang umum. Bentuk-bentuk kelembagaan tersebut kemudian ditarik ke dalam satu peradaban Timur Tengah. Penaklukan Arab di abad ke tujuh dan masa Islam selanjutnya memelihara kelembagaan-kelembagaan Timur Tengah tersebut. Kekerabatan, clientelisme dan masyarakat etnik, di tengah perubahan sejarah adalah faktor penting yang memwarnai konstruksi peradaban Islam. Ekologi wilayah terus didasarkan pada masyarakat agraris dan urban, dan ekonomi berjalan berdasarkan pada pasar dan pertukaran uang. Bentuk dasar organisasi termasuk administrasi birokrasi, gaya kehidupan beragama yang memfokuskan pada universalisme ajaran, dan kepercayaan transendental, serta semisal keorganisasian masyarakat tradisi agama lain (Kristen dan Yudaisme) mempengaruhi peradaban Islam. Cara Islam memperlakukan peradan sebelumnya adalah denga cara Islam merumuskan kembali kepercayaan agama, identitas budaya dan sosial masyarakat Timur Tengah serta mereorganisasi impirium yang mereka perintah. ${ }^{13}$

Transformasi ini, menurut Lapidus, terjadi dalam tiga fase sampai sampai tahun 1200. Pertama, pembentukkan masyarakat baru Islam di wilayah Arab sebagai hasil transformasi suatu wilayah terpencil dengan karakter umum masyarakat kekerabatan ke dalam masyarakat monotheistik dan secara politis ke alam masyarakat yang tersentralisasi. Kedua, dimulai dengan penaklukan Timur Tengah oleh masyarakat Islam arab dengan awalnya mengembangkan sistem kekhalifahan sampai pada tahun $945 \mathrm{M}$, kemudian kebudayaan dan imperium Islam. Ketiga, pada paska imperium Islam atau masa kesultanan $(945-1200 \mathrm{M})$ budaya dan kepemerintahan Khalifah masyarakat Islam ditransformasi ke dalam masyarakat yang bernegara Islam dengan kelembagaan-kelembagaan di dalamnya. Pada masa ini, Islam menjadi agama dan dasar keorganisasian komunal masyarakat Timur Tengah. Fase pertama merupakan kemunculan Islam dalam masyarakat tribal. Fase kedua Islam menjadi agama negara imperium dan elit

\footnotetext{
${ }^{12}$ Lapidus. 1988. A History of Islamic Society. P. 879

${ }^{13}$ Lapidus. 1988. A History of Islamic Society. P. 9
} 
urban. Sementara fase ketiga merupakan masa bagaimana nilai-nilai Islam dan elit urban ditransformasikan ke dalam masyarakat Timur Tengah. ${ }^{14}$

Dari perspektif toleransi, peradaban Islam sampai periode ini menginformasikan suatu sikap keterbukaan yang sangat konstruktif dimana, peradaban Islam didudukan sebagai bagian dari peradaban manusia secara keseluruhan. Sejarah berbagi pengalaman bahwa masyarakat muslim memiliki pengalaman toleransi yang membanggakan. Lapidus menjelaskan

Apapun variasinya, Islam tidak pernah merupakan satu-satunya atau prinsip total masyarakat Islam pra-modern. Setiap masyarakat Islam mewariskan dan memelihara suatu identitas budaya, organisasi kemasyarakatan, kelembagaan-kelembagaan politik, dan suatu system ekonomi yang dirumuskan dalam terma-terma non-Islam. Ekonomi masyarakat Muslim hampir tidak pernah disusun dan dilihat dalam terma-terma Islam kecuali untuk sejumlah konsep-konsep etika yang diperbaharui seperti oposisi terhadap bunga dan tuntutan atas kewajaran, keadilan dan kedermawanan. Kelembagaan-kelembagaan militer dan birokrasi, sistem perpajakan, dan legitimasi budaya negara-negara Islam selalu mempunyai dimensi nonIslam diwariskan dari budaya pra-Islam di setiap wilayah. Organisasi sosial, identitas etnik, dan kepemiminan elit dari masyarakat parochial pada umumnya juga non-Islami. Di dalam semua masyarakat Islam budaya yang dominan adalah suatu campuran antara konsep-konsep dan simbol-simbol Islam dan kelembagaan-kelembagaan dan identitas-identitas non-Islam. Bagaimanapu penting faktor Islam, Islam hanya merupakan satu aspek dari masyarakat yang lebih kompleks. ${ }^{15}$

Fase berikutnya, fase dari 1200-1800 dan fase modern 1800-sekarang. Kalau di fase sebelumnya peradaban Islam mendapat pengaruh dari tradisi Arab, Persia dan Eropa (Spanyol), peradaban Islam pada fase berikutnya (1200-1800) bersentuhan dengan tradisi lainnya seperti India, Melayu, (Indonesia,Malaysia, Brunei Daarussalam, Philipina Selatan), Cina, Turki dan Eropa khususnya bagian Timur atau negara-negara Balkan. Konstruksi peradaban Islam semakin beragam dan kompleks, bersentuhan dengan berbagai budaya lokal. Selain mendapat pengaruh dari Timur Tengah dengan tradisi Yahudi, Zoroaster dan Kriten, peraaban Islam juga sekarang bersentuhan dengan tradisi lainnya seperti India, Melayu dan Cina dengan karakter bangsanya masing-masing dan tradisi agama seperti Hindu, Budha

\footnotetext{
${ }^{14}$ Lapidus. 1988. A History of Islamic Society. P. 10

${ }^{15}$ Lapidus. 1988. A History of Islamic Society. P. 880
} 
dan dan atau faham ajaran moralnya masing-masing seperti Konfusionisme. Pada fase ini juga peradaban Islam dalam hal kenegaraan juga mengalami penyebaran wilayah setidak tiga kekuasan besar: Turki Ustmani di Timur Tengah, negara-negara Balkan an Afrika Utara, Mughal di India, Pakistan. Afganistan dan Bangladesh dan Safawi di Iran, sebagian Irak, dan sebagian Afganistan. Di sisi lain, Eropa denga terjadinya revolusi tenaga uap, mengalami kemajuan teknologi maritime, dan mulai melakukan pelayaran untuk mencari pasar sekaligus bahan-bahan yang diperlukan. Negara Portugis, Spanyol, Inggris, Belanda dan juga Perancis bayak melakukan pelayaran dan bersentuhan dengan berbagai masyarakat dunia termasuk masyarakat Muslim dari berbagai belahan dunia.

Konstruksi toleransi pada fase ini mengalami pengkayaan dimensi, baik dimensi geografis, demografis maupun dimensi budaya dan keagamaan. Pola relasi antara masyarakat Muslim dan lainnya mulai beragam juga mulai dari sebagai subyek, partner atau oposisi maupun sebagai obyek karena kekuatan lain menguasai mereka. Dalam fase ini ditemukan bahwa di samping masyarakat muslim masih memelihara model toleransi yang dilakukan masyarakat muslim di masa lalu, mereka juga mempunyai pengalaman toleransi dengan masyarakat lain. Misalnya kesultanan Turki Ustmani yang memberi perlindungan sama antara Muslim dan non-Muslim, serta memberikan kebijakan yang menghilangkan rasa takut akan pembantain bagi non-Muslim. ${ }^{16}$ Lainnya, misalnya toleransi di masa kesultanan Muslim di India juga nggak kalah penting, dimana penduduk non-Muslim tidak hanya memiliki kebebasan berpikir dan berpendapat serta kebebasan beribadah, tapi juga mereka berkesempatan untuk mempunyai kekuasaan dan privileges yang dapat mereka nikmati. ${ }^{17}$

Fase modern (1800-sekarang) peradaban Islam mengalami perubahan yang radikal yang ditandai dengan jatuhnya kekuatan politik Islam secara global dan menguatnya kekuatan politik Barat. Bangkitnya negera-negara Barat dengan revolusi mesin uap dan kekuatan maritimnya mendorong perkembangan mereka lebih lanjut, melahirkan era pencerahan dan imperialisme dan kolonialisme dimana banyak negara lain termasuk kekuatan politik Islam di banyak wilayah jatuh ke tangan mereka. Walau kekuatan politik Islam melemah dan tercerai-berai, existensi masyarakat

\footnotetext{
${ }^{16}$ Muhammad Iqbal. 2005. Islamic Toleration \& Justice: Non-Muslim Under Muslim Rule. New Delhi: Adam Publishers \& Distributors, P. 163

${ }^{17}$ Iqbal. 2005. Islamic Toleration \& Justice: p. 188.
} 
Muslim terus berkembang membangun peradaban yang disesuaikan dengan keadaan dan konteks baru. Berakhirnya imperialisme dan kolonialisme pada pertengahan pertama abad ke dua puluh, melahirkan era baru baru, yaitu lahirnya kemerdekaan negara-negara bangsa, termasuk banyak dari negara bangsa Muslim. Masyarakat Muslim dari unsur negara bangsa menambah kelompok masyarakat muslim yang tinggal di negara-negara atau kerajaankerajaan yang ada di dunia. Kebanyakan dari mereka merupakan masyarakat minoritas.

Selanjutnya, di satu sisi, gerakan modernisasi ummat manusia berkembang dan melipatgandakan kemampuan ummat manusia dalam banyak bidang seperti ilmu pengetahuan, teknologi, ilmu komunikasi yang didukung dengan perkembangan elektronik yang pesat dll. Di sisi lain, negara bangsa dengan ciri munculnya semangat nasionalisme di awal perkermbangannya dan pengaruh globalisasi yang didukung teknologi komunikasi yang mengaburkan batas-batas geografis setidaknya secara budaya, melahirkan model peradaban ummat manusia yang berbeda jauh dengan peradaban ummat manusia sebelumnya. Saat ini ummat Islam dan peradabannya menjadi bagian penting dari peradaban dunia. Nasr menyebutnya peradaban Islam "membentuk dimensi penting pada kehidupan ummat manusia saat ini." 18 Hal ini bisa dimengerti karena dengan jumlah lebih dari 1,2 milyar ummat Islam ikut membentuk pandangan dunia khususnya dari sisi kekuatan agama dalam mensinerjikan kebijakan spiritual dan kebijakan lahiriah. Muslim mulai dari bangsa Slavia dan Berber sampai Afrika, dari Arab dan Melayu, dan dari suku bangsa Turki dan Persia sampai Cina berkontribusi pada peradaban dunia. ${ }^{19}$

Konstruksi toleransi pada fase ini tidak hanya terjadi pengkayaan tapi juga pada saat yang sama tantangan baru, secara ekternal tantangan dari pencitraan global yang cenderung negatif khususnya sejak terjadinya penyerangan pesawat atas WTC dan kantor pusat FBI pada 11 September 2001 di Amerika. Adapun secara internal, tantangan datang dari relasi inter kelompok ummat Islam yang beragam dalam hal merespon gerakan modernisasi. Kemunduran politik Muslim dunia yang dimulai akhir fase 1200-1800, berlanjut sampai sekarang. Hal ini dicirikan dengan banyaknya ketergantungan negara bangsa Muslim terhadap kekuatan luar, khususnya

\footnotetext{
${ }^{18}$ Nasr. 2003. Islam: Agama, Sejarah, dan Peradaban. Pp. 1-2

${ }^{19}$ Nasr. 2003. Islam: Agama, Sejarah, dan Peradaban. 2.
} 
negara-negara Barat. Realitas banyak negara Muslim yang masih dikategorikan negara berkembang dibanding dengan negara-begara lainnya menguatkan asumsi tersebut. Konstruksi toleransi Muslim saat ini dengan demikian tidak dapat dirumuskan dengan gambaran tunggal, tapi beragam dan multidimensi. Satu hal yang menarik adalah praktek toleransi secara sosial, karena segmen ini mempunyai banyak ruang dan dinamika untuk diappresiasi.

Dari diskusi di atas dapat disimpulkan bahwa mendiskusikan toleransi dalam peradaban Islam dapat dilakukan dari berbagai sudut pandang atau titik berangkat yang berbeda, setiap pilihan mempunyai ceritanya sendiri. Diskusi selanjutnya dibatasi hanya sebatas show case saja mengambil contoh pengalaman toleransi dalam lintas peradaban Islam khususnya sampai penghujung abad pertengahan, sebelum periode modern.

\section{B. Pengalaman Toleransi Ummat Islam}

\section{Masa khulafa al-Rasyidin}

Setelah Nabi Muhammad wafat, tampuk kepemimpinan ummat Islam 27 tahun kemudian dipimpin oleh empat pengganti yang dikenal dengan Khulafa al-Rasyidin. Mereka adalah pemimpin yang dipilih setelah wafatnya Nabi Muhammad melaksanakan tugas-tugas agama dan pemerintahan. ${ }^{20}$ Salah satu perkembangan yang menonjol dari kepemimpinan Khulafa alRasyidin meluasnya interaksi sosial ummat Islam dengan kelompok sosial lainnya. Masa ini merupakan awal dari masa penaklukan ummat Islam awal atas daerah dan bangsa lainnya. Toleransi menjadi fondasi penting dari interaksi sosial ummat Islam, khususnya dengan mereka non-Muslim yang berada dibawah naungan ummat Islam. Kelompok ini bisasanya disebut $A h l$ Dzimmi. Segera setelah Khalifah Abu Bakar diangkat menjadi khalifah pertama, beliau meletakkan dasar-dasar interaksi sosial ketika ummat Islam sebagai penguasa, antara lain:

1. Orang Tua, anak-anak, dan perempuan tidak boleh di bunuh;

2. Tidaka ada hermit (orang yang mengasingkan diri) yang disiksa dan tempat tinggal mereka tidak dihancurkan;

3. Mayat diperlakukan sepatutnya dan tidak dimutilasi;

4. Pohon jangan ditebang, tanaman pokok jangan dibakar dan tidak ada lahan yang dirusak;

${ }^{20}$ Badri Yatim. 2001. Sejarah Peradaban Islam; Dirasah Islamiyah II. Jakarta: Rajawali Press, Pp. 36-7

14 | INDO-ISLAMIKA, Volume 7 No.1 Januari-Juni 2017/1438 
5. Perjanjian dengan penganut agama lain mesti dihormati dan dilaksanakan;

6. Mereka yang menyerah akan mendapat hak dan keistimewaan seperti seorang Muslim. ${ }^{21}$

Dalam setiap kesempatan Khalifah selalu berpesan, misalnya dalam suatu ekspedisi, dia dengan Usamah memeriksan pasukan, dan dia berpesan, "Saya pesan kepada kalian 10 perkara, ingatlah semuanya baik-baik. Janganlah mencuri, jangan berlaku curang, jangan melanggar janji, jangan melakukan mutilasi, jangan membunuh anak-anak dan orang tua, jangan juga membunuh perempuan, jangan menebang pohon kurma atau membakarnya, jangan menebang pohon buah, jangan menyembelih domba, sapi atau unta kecuali untuk makanan, mungkin kalian akan menemukan orang yang menyendiri, biarkan mereka dalam kesendiriannya (ujlah)." Ketika Yazid bin Abi sufyan, komandan yang memimpin pasukan Islam ke Syiria akan berangkat, Khalifah Abu Bakar mengulangi pesannya seperti yang diberikan ke Usamah dan pasukannya. ${ }^{22}$

Khalifah Umar bin Khattab juga memelihara nilai-nilai toleransi yang ada. Umar sangat memperhatikan misi Islam sebagai agama rahmatan lil 'ālamīn, sampai-sampai dalam hal hubungan dengan pihak lain yang ada dalam naungan kekuasaan dan perlindungan politik ummat Islam, Umar sangat memperhatikan hak dan kepatutan hidup (well being) anggota msyarakatnya yang non Islam. Pada kekhalifahannya, seorang sahabat Ghurfah dilaporkan oleh seorang Kristiani kepada Gubernur, Amir bin 'Ash karena ditampar oleh Ghurfah atas perlakuan Kristiani tersebut yang menghinakan Nabi Muhammad. Gubernur mengingatkan Ghurfah akan perjanjian dengan ahlu Dhimmi. Ghurfah menerima peringatan Amru bin 'Ash. Di satu sisi dia membela tindakkannya dan menjelaskan bahwa dalam perjanjian tidak termasuk poin pembolehan menghinakan Nabi. Di sisi lain dia menyadari bahwa "Mereka diberi kebebasan untuk melakukan apa yang ingin mereka inginkan di dalam gereja; apabila seseorang menyerang mereka, maka Muslim wajib melindungi mereka dari penyerangan; dan mereka tidak semestinya diberi beban di luar kemampuan mereka."23 Perhatian dan perlindungan juga tidak hanya diberikan kepada ummat Kristiani, tapi juga kepada orang Yahudi. Diceritakan bahwa ketika Yahudi

\footnotetext{
${ }^{21}$ Iqbal. 2005. Islamic Toleration \& Justice: Non-Muslim Under Muslim Rule. P. 120

${ }^{22}$ Iqbal. 2005. Islamic Toleration \& Justice: Non-Muslim Under Muslim Rule. Pp. 120-21

${ }^{23}$ Iqbal. 2005. Islamic Toleration \& Justice: Non-Muslim Under Muslim Rule. P. 121
} 
di Khaibar dan Kristiani di Najran tidak patuh memenuhi kewajiban mereka membayar administrasi tanah kuburan, Khalifah Umar tidak menghukum mereka, tapi meminta mereka mengalihkan kuburan ke tempat lain dan mereka diberi konfensasi agar bisa mengurus semuanya. ${ }^{24}$

Toleransi di zaman kekhalifahan Umar juga dipelihara dan diberikan bahkan pada aspek kebebasan beragama dan aktivitas sosial dengan batasan tidak mengganggu ketertiban dan kenyaman sosial. Mereka bebas melaksanakan ajaran agamanya. Larangan hanya dilakukan pada pemukulan lonceng atau peniupan trompet pada saat ummat Islam melakukan ibadah sholat jama'ah, karena dianggap akan mengganggu pelaksanaan ibadah. Pembatisan diperbolehkan bagi anak-anak mereka. Hanya bagi anak yang sudah masuk Islam, tawaran pembaptisa mesti dilakukan serelah anak tersebut bisa melakukan pilihan sendiri. Pemerintahan Islam sangat menjaga kekebasan beragama, bahkan Budak yang bekerja di rumah Khalifah Umar, Istaq tidak dipaksa untuk beragama Islam dan Umar tidak marah atas penolakan Istaq atas permiantaan Kalifah untuk masuk Islam, seraya mengatakan bahwa tidak ada paksaan dalam beragama. ${ }^{25}$

Khalifah Umar dalam suatu pembunuhan seoran Kristen Hirite oleh seorang Muslim, dia menyerah muslim tersebut kepada pengganti orang yang dibunuh, secara membela bahwa "kedamaian in diberikan oleh abdi Tuhan, Amir al-Mu'minin, Umar, kepada masyarakat Leliya untuk memelihara hidup, harta benda, gereja-gereja, mereka yang sehat dan yang sakit dan pengankaut agama mereka. Gereja mereka jangan dijadikan tempat tinggal, dan janga pula dihancurkan. Jangalah batas wilayah mereka tidak dihancurkan, mengakibatkan kehilangan. Jumlah salib dan kekayaan mereka jangan dikurangi, dan mereka tidak akan dipaksa untuk memeluk agama Islam..."26

Ketika perang antara kehalifahan Islam dan Imperium Romawi, Khalifah Umar memberi contoh toleransi yang menyentuh, "Pimpinan gereja (the patriarch) Yerusalem setelah dikepung dalam waktu yang lama, menawarkan penyerahan kota kepada ke khalifahan Islam kalau Khalifah sendiri yang datang di kota tersebut untuk menerimanya. Umar menerima tawaran tersebut. Beliau di terima di gerbang dan di antar melalui kota berdiskusi berbagai hal. Ketika mereka sampai di Gereja Kebangkitan, saat

\footnotetext{
${ }^{24}$ Iqbal. 2005. Islamic Toleration \& Justice: Non-Muslim Under Muslim Rule. P. 122

${ }^{25}$ Iqbal. 2005. Islamic Toleration \& Justice: Non-Muslim Under Muslim Rule. P. 123

${ }^{26}$ Iqbal. 2005. Islamic Toleration \& Justice: Non-Muslim Under Muslim Rule. P. 124-5
} 
waktunya sholat bagi Muslim tiba. Secara baik pimpinan gereja menawarkan tempatnya bagi Khalifah untuk mendirikan sholat. Khalifah menolaknya secara halus sambil menjelaskan bahwa jika dia menerima tawarannya, maka dimasa akan datang muslim melanggar perjanjian seperti ini dengan dalih mengikuti jejakku. Sebagai sholat di dalam katederal, Umar mendirikan sholat di antara tangga masuk di depan katederal.",27

Contoh toleransi lainnya dalam bidang administrasi publik. Sejumlah orang juga ditemukan pada penganut agama lain yang berada dalam perlindungan Islam diminta untuk mengusrus administrasi pendapatan negara. Menurut al-Balazuri dalam Ansabnya, Khalifah menyurati Gubernurnya di Syria untuk mengirim seorang Yunani Kristen untuk mengurus administrasi dan diberi kewenangan sebagai ketua keuangan departemen di Kota Nabi dan seorang penganut Zoroaster dan Magian untuk mengurus urusan administrasi di Mesir. ${ }^{28}$

Khalifah Umar bin Khattab dibunuh oleh Abu Lulu, salah satu budaknya seorang Persia yang tadinya beragama Kristen berganti menjadi penganut Zoroaster. Pembunuhan tersebut memicu pembunuhan balasan atas Abu Lulu oleh anaknya Umar. Banyak sahabat tidak berkekenan dengan tindakan main hakim sendiri putra Umar, karena mencederai semangat keadilan Islam. Keadilan terbunuhnya Umar semestinya ditegakkan oleh negara dan bukan oleg perorangan. Khalifah Ustman bin Affan sebagai pengganti Umar sebenarnya kurang setuju dengan keberatan sebagian sahabat, karena tindakan keluarga Umar ada dalam konteks masa itu dapat dimenegrti, dia tetap menjaga semangat toleransi dengan cara memberi sejumalh uang kepada keluarga yang ditinggalkan. Secara umum Utsman juga menjaga nilai-nilai toleransi yang sudah digariskan dalam al-Qur'an dan Sunnah dan dipraktekkan oleh dua pendahulunya. ${ }^{29}$

Khalifah Ali bin Abi Thalib, pengganti Ustman bin Affan, dikenal sebagai orang yang berilmu dan bijaksana. Terhadap non Muslim yang dalam perlidunga kekhalifahan, Ali bersikap simpati dan selalu memikirkan peningkatan keadaan mereka. Misalnya salah seorang pengumpul pajak dan keuanga negara, Amr bin Muslimah, dilaporkan kepada Khalifah Ali oleh Ahl Dhimmi. Ali langsung berkirim surat dan mengatakan bahwa "Saya mengetahui bahwa sikap anda terhadap Ahl Dimmi kasar. Tidak ada

\footnotetext{
${ }^{27}$ Iqbal. 2005. Islamic Toleration \& Justice: Non-Muslim Under Muslim Rule. P.124

${ }^{28}$ Iqbal. 2005. Islamic Toleration \& Justice: Non-Muslim Under Muslim Rule. P. 126

${ }^{29}$ Iqbal. 2005. Islamic Toleration \& Justice: Non-Muslim Under Muslim Rule. Pp. 132-33
} 
kebaikan dalam tindakan terlalu keras. Kamu semestinya menggunakan ketegasan dan proporsionalitas. Akan tetapi sikap tegas jangan sampai pada point tindak kekerasan dan tidak juga sikap baik yang akan mendatangkan kerugian. Anda mesti menyadari bahwa negara meminta upeti atau pajak dari mereka tapi dalam pelaksanaannya jangan sampai tangan kamu berlumuran darah mereka." 30 Lebih jauh, Ali tidak hanya menyurati atau memperingatkan pihak muslims untuk berlaku baik terhadah ahl dhimmi, dia terkadang menanyakan langsung apakah petugas Muslim memperlakukan mereka dengan baik atau tidak dalam kejadian seorang Muslim membunuh ahl Dhimmi. Kemudian muslim itu di proses secara hukum dan pada akhirnya keluarga korban memaafkan dia. Kemudian Ali memanggil keluarga korban dan menanyakan apakah mereka terpaksa memberikan maaf kepada muslim yang telah membunuh salah satu anggota keluarga mereka. Mereka menjawab bahwa mereka tidak pernah mengalami pemaksaan apapun. $^{31}$

\section{Masa Khilafah Bani Umayyah dan Khilafh Bani Abbas}

Seperti di kekhalifahan sebelumnya, pengalaman praktek toleransi pada masa Bani Umayyah dan Bani Abbas memiliki semangat yang sama, yaitu menjaga pesan Islam sebagai agama rahmat bagi alam semesta dengan fokus memberikan proteksi keamanan, kebebasan beragama, menjaga kelayakan hidupdan lebih jauh melakukan upaya integrasi sosial dengan kebijakn non diskrimiasi terhadap non-Muslim dalam banyak hal termasuk dalam hal urusan kepentingan umum dan negara. Perbedaan waktu dan konteks memberi dinamika dan nuansa lain dari praktek toleransi dalam peradaban Islam masa-masa ini. Di bawah kekhalifahan Bani Umayyah dan Bani Abbas, di pusat atau provinsi melarang penganiayaan ahl Dhimmi dan masyarakat non-Muslim lainnya. Kepentingan mereka dilindungi dan kebebasan mereka dibela. Seperti di masa kekhalifahan al-rasydin, di masa kekhalifahan Bani Umayyah dan Bani abbas juga memperhatikan kebebasan beragama, konsumsi dan belanja termasuk apa yang dalam agama islam dilarang dan dalam agama mereka tidak. Dalam menjaga pesan agar menjadi rahmat bagi sekalian alam (manusia), praktek toleransi diperhatikan oleh berbagai pihak; negara sebagai penjaga utama, tapi tekadang negara lalai,

\footnotetext{
${ }^{30}$ Iqbal. 2005. Islamic Toleration \& Justice: Non-Muslim Under Muslim Rule. Pp. 134-5

${ }^{31}$ Iqbal. 2005. Islamic Toleration \& Justice: Non-Muslim Under Muslim Rule. P. 135
} 
maka pihak lain seperti ulama, masyarakat pada umunya dan bahkan ahl Dhimmi sekalipun menjadi bagian yang memelihara toleransi ini. Toleransi memberi dampak keterbukaan ummat Islam terhadap masyarakat lainnya, keterbukaan ini tidak hanya untuk koeksistensi tapi juga menuntut ilmu. Dua ulama besar misalnya, Imam Abu Hanifah dan Imam Syafi'i melihat tidak ada halangan bagi non-Muslim untuk belajar Islam, seperti belajar alQur'an, Sunnah, dam Fiqh. Masyarakat non-Muslim juga diberi kesempatan untuk ikut serta dalam administrasi negara bahkan sampai level pimpinan strategis. Sementara pimpnan tertinggi seperti khalifah dipandang hanya untuk ummat Islam karena mengemban misi spiritual keagamaan disamping kenegaraan. ${ }^{32}$

Beberapa contoh di masa Bani Umayah, di masa Umar II, walau hanya 2 tahun memerintah, tapi perhatiannya ada toleransi perlu dicatat. Dia memerintahkan seluruh jajarannya untuk memperhatikan ahli dhimmi. Hal ini terlihat jelas dalam beberapa pesannya kepada gubernur dan jajaran pemerintahannya, "Perhatikan keadaan kelompok masyarakat yang dilindungi (non-Muslim), dan perlakukan mereka dengan lembut. Kalau di antara mereka menjadi jompo, dan tidak memiliki sumber kehidupan, ini adalah tanggung jawab anda untuk memperhatikannya. Kalau dia mempunyai kontrak dimana dia punya hak, maka bantulah agar dia mendapatkan haknya..." dan pesan lainnya, "bebaskanlah mereka yang diminta membayar pajak secara tidak adil dan pelajari dokumen lama. Kalau seandainya ditemukan ketidakadilan terhadap Muslim atau non-Muslim, kembalikan haknya. Kalau mereka sudah meninggal, maka berikan haknya kepada ahli warisnya." Khalifah tidaj hanya berpesan tapi juga bertindak. Ketika masyarakat Kristiani mengadu kepadanya tentang tanah dan tempat tinggal dimana sebagaiannya merupakan tempat beribadah mereka yang berpindah pengelolaan kepada Muslim. Khalifah setelah tahu duduk perkaranya segera meminta agara rumah dan tanah tersebut dikembalikkan kepada ummat Kristiani yang memang merupakan pemilik sebelumnya. Kasus seperti ini sering terjadi dan ahlu dhimmi mendapat haknya kembali. Pada situasi ummat Islam sangat memerlukan tempat untuk kepentingan publik Islam secara umum, seperti mesjid, penguasa mempersuasi ummat lain agar mempunyai pengertian. Dan Hal ini terjadi dimana kaum Kristiani merelakan tanahnya untuk di bangun mesjid jami. Di lain kesempatan

\footnotetext{
${ }^{32}$ Iqbal. 2005. Islamic Toleration \& Justice: Non-Muslim Under Muslim Rule. Pp. 142-53
} 
Khalifah Umar II bahkan mengganti Usamah dengan lainnya sebagai Gubernur karena dianggap dia sudah menekan ahl dhimmi kristiani. Bahkan ketika salah satu anggota penting Bani Umayyah, Muslimah bin Abdul Malik berselisih dengan pengurus gereja, dalam persidangan Khalifah Muslimah tidak diperkenankan untuk berbicara. Ketika keputusan dibacakan, hasilnya membela pengurus gereja. Hal ini dilakukan untuk menjaga peran Islam sebagai agama rahmat. ${ }^{33}$ Komandan pasukan Ubaidillah di masa kekhalifahan Hisyam ketika berhasil menaklukan Sudan, dia berjanji kepada masyarakat Sudan bahwa "sejak saat ini keamanan hidup akan diberikan kepada semua. Tidak ada aksi balas dendam bagi perbuatan yang terjadi sebelum penaklukan. Praktek keagamaan mereka tidak akan diganggu. Mereka yang akan meneruskan keagamaan sebelumnya, hanya dibebani untuk membayar jizyah (bantuan biaya untuk keperluan militer dan sebagai imbalan mereka berhak mendapat perlindungan). Kekayaan mereka dan harta lainnya akan terus dilindungi. Kekhalifahan Islam bertanggungjawab atas perlindungan tersebut." 34

Sementara beberapa contoh praktek toleransi di zaman kekhalifahan Bani Abbas dapat dirujuk dalam beberapa kejadian. Antara lain, pada masa kekhalifahan Hadi, diceritakan bahwa Ali bin Sulaiman, gubernur Mesir, telah membongkar beberapa katedral. Harun al-Rasyid, khalifah pengganti Hadi, mengangkat kembali kasus ini dan mengganti Ali bin Sulaiman sebagai gubernur dengan Musa bin Isa setelah mendengar pendapat para ulama. Ulama yang diminta pendapatnya bersepakat berpendapat bahwa gereja-gereja yang telah dihancurkan di masa kekhalifahan sebelumnya mesti dibangun kembali dengan biaya negera. Para selain diminta pendapatnya tentang sesuatu pendapat atau hukum berkaitan dengan toleransi, terkadang ikut berperan aktif dengan mengingat khalifa atau aparatnya apabila mereka melakukan kelalaian. Seperti apa yang dilakukan, Imam Abu Yusuf menyurati Khalfah Harun al-Rasyd, "Adalah tugas anda untuk menunjukka kasih sayang Islam terhadap ahl Dhimmi. Perhatian seperti ini telah dipraktekkan sebagai kegiatan rutin Nabi Islam. Jangan sampai anda tidak mengetahui kebutuhan mereka. Mereka jangan sampai dipaksa dan ditekan. Jangan merampas harta benda mereka, kecuali anda meminta jizyah. Anda pasti tahu pesan akhir Nabi dan dua Sahabatnya, Abu Bakar dan Umar,

\footnotetext{
${ }^{33}$ Iqbal. 2005. Islamic Toleration \& Justice: Non-Muslim Under Muslim Rule. Pp. 145-7

${ }^{34}$ Iqbal. 2005. Islamic Toleration \& Justice: Non-Muslim Under Muslim Rule. P. 147
} 
'Wahai kamu Muslim, Anda mesti berbuat baik kepada Dhimmi, perlihatkanlah toleransi kepada mereka dan janganlag ganggu mereka." 35

Contoh lain perlu disebut di sini adalah praktek toleransi di masa Khalifah Makmun al-Rasyid. Makmun memberi ruang dan kesempatan yang luas kepada non-Muslim. Dalam hal agama, misalnya, dia tidak ingin seseorang memeluk Islam karena terpaksa, dipaksa atau alasan sosial ekonomi. Dia hanya menerima seseorang masuk Islam karena tujuan yang lebih mulia, di luar hanya tujuan-tujuan duniawiyah. Suatu ketika Rezdan Bakht, ketua Manwite, datang ke Bagdad. Dalam suatu perdebatan, para ulama berhasil mementahkan pendapat-pendapatnya dengan argumentasi yang kuat. Tapi Khalifah tidak berhasil menyakinkan Bakht untuk memeluk Islam. Saat dia berpamitan, Khalifah mengirim pengiring bagi Bakht untuk menjaga keselamatan selama perjalanan. Mendapat perlakuan yang baik, hati tereyuh dan dia akhirnya memeluk Islam. ${ }^{36}$

Sementara contoh non-Muslim mempunyai kesempatan untuk menduduki amanah publik juga terbuka seperti Muslim. Banyak dari kalangan Kristian, Yahudi dan penganut Zoroasterism memegang amanah publik. Ya'kub bin Killis, Yahudi asal Bagdad awalnya beragama Yahudi yang kemudian memluk Islam, terpilih untuk memgang amanat menjadi wazir pertama Fathimiyah dengan pertimbangak keefektifan mamjemennya dan kemampuannya dalam hal pengembangan ekonomi masyarakat. Lainnya, Isa bin Nasturus dan Mansur bin Abdun, penganut Kristianitas, juga diamanati menjadi wazir. Mannaseh, awalnya penganut Yahudi, ditunjuk sebagai gubernur Syria. Fadh bin Marwan, seorang Kristen, ditunjuk sebagai salah satu perdana menteri kekhalifahan Abbasiyah. Penganut Kristianitas Nestorian banyak yang diminta untuk mengurus Baet al-Hikamh. Banyak orang Yahudi dan Kristian yang menjadi ahli kesehatan, penerjemah, guru d1l. ${ }^{37}$

Di masa kekhalifahan Harun al-Rasyd, perlakuan negara kepada pemuka agama dan institusinya diperlakuakn secara sama. Dlam sebuah surat resmi negara tahun 533/1139, Khalifah menyatakan, "Pertemua resmi kaum Kristiani telah memlih penanggung untuk mengurus urusan mereka; untuk menadministrasi harta benda mereka; untuk mengatur diantara mereka yang kuat dan yang lemah. Menurut tradisi lama, mereka mesti menyerahkan

\footnotetext{
${ }^{35}$ Iqbal. 2005. Islamic Toleration \& Justice: Non-Muslim Under Muslim Rule. Pp. 148-9

${ }^{36}$ Iqbal. 2005. Islamic Toleration \& Justice: Non-Muslim Under Muslim Rule. P. 149

${ }^{37}$ Iqbal. 2005. Islamic Toleration \& Justice: Non-Muslim Under Muslim Rule. Pp. 151-2
} 
siapa yang mereka pilih kepada pemerintah setempat, dan sebagai Imam, saya memberikan izin kepada anda sebagai Katholik Nestorian di kota yang damai (Bagdad) dan di wilayah-wilayah kekuasaan Islam lainnya, dan juga agar menjadi otiritas kepada Yunani dan kaum Yakobis serta Melkites di seluruh wilayah imperium.... Saya selanjutnya memerintahkan bahwa kamu dan masyarakat kamu dilindungi dalam hal kehidupan dan harta benda. Kamu mesti memediasi antara sekte-sekte Kristiani dalam hal perselisihan dan membantu yang lemah dalam hak mereka terhadap yang kuat." 38

\section{Kekuasaan Islam di Spanyol}

Kekuasaan Islam di Spanyol berlangsung cukup lama, delapan ratus tahunan yang dapat dibagi ke dalam enam periode: pertama (711-755), pada masa kekuasaan Bani Umayyah, kedua (755-912) masa kekuasaan Bani Abbas, ketiga (912-1013) proklamasi kekhalifahan Bani Umayyah di Spanyol dengan khalifah Abdurahman III atau an-Nasir, ditandai dengan memanfaatkan momen wafatnya khalifah al-Muktadir dari dinasti Bani Abbas di Bagdad, keempat (1013-1086) masa dimana kekuasaan Islam di Spanyol terpilah-pilah ke dalam lebih dari 30 kerajaan kecil, dikenal dengan al-Muluk al-Thawaif, diantara yang terkenal bertempat di Sevilla, Cordoba dan Toledo, kelima (1086-1248) masa munculnya dua kekuatan dominan di tengah kerajaan-kerajaan Islam kecil: Murabithun (1086-1142) dan Muwahiddun (1146-1235), keenam (1248-1492) masa kekuasaan Islam hanya tersisa di Granada dibawah dinasti Bani Ahmar (1232-1492). ${ }^{39}$ Walaupun kekuasaan Islam di Spanyol selama delapan abad diwarnai dengan peperangan yang disebut dengan Perang Salib yang berlangsung kurang lebih dua abad, 11 dan $12 \mathrm{M}$, menunjukkan sebenarnya adanya ruang yang cukup lebar baik dimasa peperangan salib ataupun diluar masa tersebut dimana secara budaya ummat Islam dan non-Muslim saling berinteraksi. Dalam rentang waktu dari 711 M sampai 1492 M tentunya banyak pengalaman tentang toleransi, tapi hanya beberapa pengalaman saja akan disinggung di sini. Thariq bin Ziyad, komandan perang zaman Khaoifah bin Nushair, ketika berhasil membuat perjanjian damai dengan orang Spanyol, berbicara di depan pasukannya bahwa "tidak akan ada ientervensi dalam urusan agama Kristen. Tempat-tempat ibadah mereka tidak akan

\footnotetext{
${ }^{38}$ Iqbal. 2005. Islamic Toleration \& Justice: Non-Muslim Under Muslim Rule. Pp. 151-2

${ }^{39}$ Yatim. 2001. Sejarah Peradaban Islam. Pp. 93-100
} 
dihancurkan. Mereka akan mempunyai kebebasan penuh untuk berbicara dan menulis. Kita akan bertanggungjawab akan kehidupan dan harta benda mereka. Kita hanya memberi kewajiban kepada mereka untuk membayar jizyah yang ringan. Garansi yang akan diberikan ummat Islam adalah bahwa dia akan dihormati dalam praktek keagamaannya..." Hal yang sama dilakukan oleh Ibn Musa Ibn Musa, penguasa Arab lainnya. Secara umum, penguasa Arab memberi sentuhan kesabaran dan keramahan dalam struktur pemerintahannya di Spanyol. Masyarakat Yahudi dan Kristiani dihimbau untuk berbaur dalam berbagai kegiatan kebudayaan, termasuk pertukaran dan saling menimba ilmu pengetahuan dan teknologi. ${ }^{40}$

Kekuasan Bani Umayyah di Spanyol yang didirikan oleh Abdu Rahman al-Dakhil, berlangsung dari 756-1031 M, mengenalkan praktek pemilihan pegawai yang bertugas khusus mengecek hak dan keistimewaan ahli Dhimmi. Kepala gereja dibebaskan untuk memakai kebesaran pakainnya dan bergerak bebas dalam pelaksanaan upacara keagamaannya. Apabila ada warga muslim mengganggu warga non-Muslim, mereka ditindak dengan tegas. Anak-anak non-Muslim bisa sekolah dan bahkan menerima bantuan biaya sekolah seperti warga Muslim. Diceritakan bahwa Abdurahman II memberikan beasiswa kepada anak-anak non-Muslim. ${ }^{41}$

Perlu dicatat disini dampak dari memelihara hubungan baik antara ummat Islam dan non-Muslim terhadap perkembangan peradaban khususnya ilmu pengetahuan. Sumbangan ilmu pengetahuan orang Islam dapat dirunut dalam gerekan penerjemahan Barat. Sampai abad 12 M keteika perang Salib terjadi, lahir sekolah-sekolah penerjemahan Andalusia, khususnya sekolah di Toledo. Barat melakukan kerja sistematis menerjemahkan khasanah ilmuilmu Islam ke dalam bahasa Latin. Bahasa Latin, ketika itu merupakan bahasa pengetahuan seluruh Eropa dan bahasa sehari-hari sebagian besar penduduk Spanyol. Gerakan ini dari perspektif ummat Islam, dapat dilihat sebagai sumbangan peradaban Arab Islam mulai mempengaruhi Eropa dan berlangsung tibad kemudian, meninggal pengaruh nyata dan mendalam. Sekalipun kebesaran sekolah penerjemahan di Spanyol tidak sebesar sekolah penerjemahan di Bagdad, tapi gerekan penerjemahan ini berperan penting dalam menyebarkan ilmu pengetahuan warisan ummat Islam Arab di kalangan intelektual Eropa dan berpengaruh terhadap ilmu pengetahuan

\footnotetext{
${ }^{40}$ Iqbal. 2005. Islamic Toleration \& Justice: Non-Muslim Under Muslim Rule. Pp. 154-5

${ }^{41}$ Iqbal. 2005. Islamic Toleration \& Justice: Non-Muslim Under Muslim Rule. Pp. 156
} 
Barat Abad pertengahan. Dengan kata lain warisan ilmu pengetahuan yang berhasil diserap dan dikembangkan dari budaya bangsa "Mesir, Babylonia, Asyiria dan Phoenesia yang kemudian bergerak ke Yunani, dan kembali lagi dalam bentuk peradaban Yunani, yang telah diadopsi oleh orang-orang Arab dan yang telah mereka tambahi dengan aspek-aspek tertentu dari sumbersumber India yang telah ditiru oleh Persia. Peradaban Yunani ini mereka perbesar dengan usaha-usaha kreatif, dan mereka seberangkan melalui Afrika ke Spanyol, dari sana arus besar itu menyebar ke pusat-pusat ilmu Arab di Perancis, Jerman, Italia, Inggris, dan semua daerah di Eropa Barat dan Selatan. ${ }^{~} 22$ Contoh kongkrit sumbangan tersebut adalah ilmu geography dan kelautan. Salah satu ilmu pengetahuan yang membantu pengembangan ilmu pengetahuan Eropa adalah ilmu geography dimana pada masa pencerahan, orang-orang Eropa berhasil menjelajah ke berbagai pelosok bumi baik untuk kepentingan pencarian bahan baku, pasar produk mereka atau untuk kepentingan koloniaslime dan imperelisme. Mengiringi gerakan tersebut, Bangsa Eropa banyak dibantu dengan ilmu pengetahuan yang ada. Ketika itu banyak karya seputar geography di tulis oleh orang-oran arab Islam. Dan karya-karya tersebut dapat diakses secara luas salah satunya sebagai dampak gerakan terjemahan yang mereka lakukan. Banyak karya yang menceritakan daerah-daerah seperti Asia Selatan dan Timur, serta Afrika Utara. Penjelajahan orang Arab yang diveritakan dalam buku-buku digambarkan penulusuran daerah-daerah pantai Timurnya sampai wilayah yang disebut Tropic of Capricorn. Mereka melukiskan daerah secara terinci dari mulai Korea sampai Laut Kegelapan, Laut Arctic, dan membuat catatan aspek-aspek geographis dari kawasan yang sangat luas tersebut. Ilmuan seperti al-Mas'udi, al-Biruni dan Hasan bin Muhammad al-Wazzan alZayyaf banyak banyak dirujuk. Misalnya, al-Zayyaf yang hidup lama di Eropa menulis buku Deskrifsi Afrika, memaparkan secara detail geography benua Afrika. ${ }^{43}$

\footnotetext{
${ }^{42}$ Komisi Nasional Mesir untuk UNESCO. 1986. Sumbangan Islam Kepada Ilmu Pengetahuan dan Kebudayaan. Bandung: Penerbit Pustaka, pp. 254-6.

${ }^{43}$ Komisi Nasional Mesir untuk UNESCO. 1986. Sumbangan Islam Kepada Ilmu Pengetahuan dan Kebudayaan. Pp. 257-8
} 


\section{Toleransi di Tiga Kerajaan Besar: Kesultanan Turki Usmani, Kesultanan Safawi, dan Kesultanan Mughal India}

Kesultanan Turki Usmani didirikan oleh kabilah Oghuz yang mendiami daerah Mongol dan Utara negeri Cina. Sebelum masuk Islam pada kira-kira abad 9 atau $10 \mathrm{M}$, mereka menyebar ke Persia dan Irak dan menetap di Asia Tengah. Mendapat tekanan dari Mongol dan pada abad ke 13 mereka mengunsi di daerah Asia Kecil di tempat sudara-saudara mereka , orang Turki Seljuk. Dibawa kepemimpnan Ertoghrul, mereka mengabdi kepada Sultan Alauddin II, yang sedang berperang dengan Byzamtium. Sepeninggalnya Ertoghrul tahun 1289, puteramya, Usmani, menggantikannya. Usmani inilah yang dianggap sebagai pendiri kesultanan Turki Usmani yang memerintah dari 1290 sampai 1326 M. Pada tahun 1300 keultanan Seljuk diserang dan setelah itu daerah kekuasaannya terpecahpecah. Pada saat seperti itulah kemudian Usman menyatakan kemerdekaannya dan berkuasa penuh atas daerah yang didudukinya. Setelah itu kesultanan Turki Usmani meluas melingkupi daerah Broessa (perbatasan dengan Byzamtium), Azmir, Thawasyanli, Uskandar, Angkara dan Gallipoli, dan beberapa daerah di Eropa seperti Andrianopel, Macedonia, Sopia, Salonia dan seluruh wilayah Utara Yunani. Pada perkembangannya Turki Usmani dapat menguasai Byzamtium dan Konstantinopel di zaman Sultan Muhammad Fatih. Perluasan kemudian diarahkan ke sebelah Timur dan daerah daerah Persia, Stiria dan mamalik di Mesir di kuasai. Berikutnya Irak, Belgrado, Pulau Rodhes, Tunis, Budapest dan Yaman dikuasai di abad enam belas masehi. ${ }^{44}$

Sementara kesultanan Safawi berasal dari sebuah gerakan tarekat Safawiyah beraliran Syi'ah yang berdiri di Ardabil, Azarbaijan, berbarengan dengan berdirinya kesultanan Turki Usmani. Pendiri Tarekat Safawi adalah Safi'u al-Din (1252-1334), keturunan Musa al-Kazhim, berguru ke Syekh Taj al-Din Ibrahim Zahidi (1216-1301), dikenal sebagai Zahid al-Gilani, dan nikah kepada putri gurunya. Dia mendirikan tarekat Safawiyah setelah ia menggantikan gurunya tahun 1301. Mulanya gerakan tasawuf ini bertujuan untuk memerangi orang-orang ingkar dan bid'ah, tapi kemudian menjadi gerakan politik terutama ditangan murid-muridnya dimana gerakan ini meluas meliputi Persia, Syiria, dna Anatolia. Gerakan terekat ini kemudian menjadi gerakan politik praktis dalam kemepimpinan Juneid(1447-1460).

\footnotetext{
${ }^{44}$ Yatim. 2001. Sejarah Peradaban Islam. Pp. 129-33
} 
Sejak itu, perlawanan demi perlawanan terhadap penguasa Islam lain terus terjadi, tapi baru Ismail cucunya Juneid berhasil mendirikan kesultanan Persia. Di masa Ismail, kesultanan berhasil menaklukan Tabriz tahun 1501, Hamadan tahun 1505, Kaspia darerah Nazardaran, Gurgan, dan Yazd tahun 1504, Diyar Bakr 1505-1507, Bagdag dan Barat Daya Persia 1508, Sirwan 1509, Khurasan 1510. Sempat mengalami kemundurun setelah Ismail, untuk kemudian Kesultanan Safawi mengalami kejayaan kembali di zaman Abbas I (1588-1628). Abbas I berhasil menguasai Herat, berhasil menguasai kembali Tabriz, Sirwan, dan Bagdag, ditambah dengan penguasaan daerah lain Nakhchivan, Erivan, Ganja dan Tiflis (1605-1606), kepualauan Hurmuz 1622, dan mengubah pelabuhan Gumrun menjadi Bandar Abbas. ${ }^{45}$ Leluhur negara Iran sekarang dapat dipandang sebagiannya sebagai bagian yang tersisa dari kesultanan Safawi.

Terakhir, Kesultanan Mughal India berdiri seperampat abad setelah berdirinya kerajaan Safawi. Kerajaan ini sebenarnya bukan kerajaan islam pertama di India, kekuasaan Islam mulai masuk India di zaman kekhalifahan al-Walid (705-715) dinasti Bani Umayyah, ditaklukan oleh pasukan tentara dibawah komando Muhammd ibn Qasim. Kerajaan Mughal di India didirikan oleh Zahiruddin Babur (1482-1530), salah satu cucu Timur Lenk, dengan daerah kekuasaan awal di Ferghana, warisan dari ayahnya, Umar Mirza. Dengan bantuan Safawi, Babur berhasil menguasai Samarkand pada tahun 1494 dan Kabul 1504. Memanfaatkan situasi yang ada, Babur kemudian mengusai Punjab tahun 1525, dan kota Delhi 1526 yang kemudian kota ini dijadikan ibu kota kerajaan Mughal. Kesultanan India meraih puncak kejayaannya pada zaman Akbar, cucu pendiri kesultanan. Pada zamannya perluasan daerah kekuasaan kesultanan banyak dilakukan. Akbar berhasil menguasai Chundar, Ghond, Chitor, Ranthabar, Kalinjar, Gujarat, Surat, Bihar, Bengal, Kashmir, Orissa, Deccan, Gawilgarh, Narhala, Ahmadnagar, dan Asirgah. Di antara raja-raja besar Mughal lainnya adalah Jehangir (1605-1628), Syah Jehan (1628-1658), dan Aurangzeb (1658-1707). ${ }^{46}$

Secara umum, sejarah tiga kesultanan besar ini diwarnai dengan penaklukan dan peperangan memperebutkan atau mempertahankan kekuasaan. Kelihatannya kebijaksanaan umum yang dipegangi hampir universal pada zaman itu adalah untuk mewujukan perdamaian, toleransi dan

\footnotetext{
${ }^{45}$ Yatim. 2001. Sejarah Peradaban Islam. Pp. 138-43

${ }^{46}$ Yatim. 2001. Sejarah Peradaban Islam. Pp. 145-51
} 
perkembangan, perlu ditegakkan terlebih dahulu kestabilan. Dari kebanyakan kasus, kestabilan suatu imperium, kesultanan, atau kerajaan sering terwujud setelah suatu kekuasaan mampu membangun pertahanan bagi negerinya dan perlindungan bagi rakyatnya. Oleh karena itu dapat dimengerti kalau kemudian praktek toleransi yang terjadi pada zaman seperti ini, seperti yang disebut Bernard Lewis toleransi dari pihak penguasa. Namun demikian, adanya hal demikian merujuk pada konteks yang ada, merupakan sesuatu yang mencerahkan. Tidak heran, kalau dalam masa penaklukan dan perkembangan Islam, Islam mendapat penerimaan yang luar biasa dan menjadi precedence sejarah dimana manusia selanjutnya termasuk zaman kta sekarang bisa mengambil pelajaran untuk bisa hidup berdampingan dengan kelompok berbeda, agama, etnik atau lainnya.

Contoh toleransi di masa kesultanan Turki Usmani diwarnai dengan praktek kebijakan ekslusif yang pada gilirannya menyulitkan praktek toleransi seperti yang terjadi di kekuasaan Islam lainnya pada zaman dan tempat yang berlainan. Kebijakan tersebut adalah devshrime, millat system, kapitulasi, dan tanzimat. Devshrime berarti "mengumpulkan", digunakan untuk rekrutmen wajib bagi anak-anak keluarga Kristiani untuk dilatih dan akhirnya direkrut sebagai pegawai pemerintah atau anggota militer. Sultan Murad II (1421-1451 M) merasa perlu memperkuat kekuatan militernya di Istambul. Mereka kemudian dipastikan mengikuti keimanan Islam dan setia kepada sultan. ${ }^{47}$ Millat berasal dari al-Qur'an "millah" berarti Muslim sebagai komunitas agama, atau berarti negara Islam. Dalam kesultanan Turki Usmani terma tersebut kemudian digunakan untuk mengelommpokkan masyarakat beragama dengan memberi ruang toleransi dalam ruang komunitas beragama masing-masing dengan maskud untuk memberi ruang loyalitas kepada negara lebih kuat ditengah penghormatan keragaman beragama yang ada. Perbedaan dengan prakek toleransi dengan masa sebelumnya adalah loyalitas kepada negara terkonstruksi secara alamiah, sementara pada masa kesultanan Turki Usman direkayasa. Respon yang terjadi adalah terjadinya keterpaksaaan loyalitas kepada negara tapi eksesnya kemudian muncul sikap eksklusivitas dikelompok-kelompok agama non Islam. Seperti kelompok Kristiani yang menunjukkan sikap mementingkan

${ }^{47}$ Iqbal. 2005. Islamic Toleration \& Justice: Non-Muslim Under Muslim Rule. Pp. 172-4

INDO-ISLAMIKA, Volume 7 No.1 Januari-Juni 2017/1438 | 27 
kelompokknya sendiri daripada memerhatikan negara dimana mereka tinggal. ${ }^{48}$

Kapitulasi dapat merujuk pada suatu perjanjian dalam mana otoritas asing dapat menikmati hak untuk memiliki wewenang lebih di Imperium Timur Teangah. Kewenangan tersebut bisa di bidang perdagangan, pendidikan, dan hukum. Kesultanan Turki Usmani menggunakan kebijakan sebagai strategi komunikasi politik dan tranformasi peradaban. Misalnya hak kapitulasi diberikan kepada Perancis di zaman Sulaiman dengan nama "Persahabatan dan Perdagangan". Pada prakteknya menurut merujuk Bernad Lewis, Iqbal menjelaskan bahwa system ini menjadi "sumber eksploitasi besar dari sisi negara yang menjadi perhatian, dan penerima asing." Bernad Lewis menjelaskan, "salah satu tujuan utama dari perubahan-perubahan ini adalah untuk merespok kritik asing terhadap keadilan Tuski Usmani, dan terus menyiapkan jalan untuk penggantian atau pembatasan hak istimewa peradilan asing yang diakui dalam rekapitulasi. Dalam hal ini legislator Turki Usmani berhasil. Hukum peradilan dan prosedur civil tidak diakui oleh misi asing, dan konsekwensinya tidak pernah dipraktekkan peneggakkan hukum yang menggabungkan antara hukum asing dan lokal. Keutamaan lebih territori komunitas asing tetap mapan, dan peradilan kesultanan terbatas dalam kompetensinya atas kasus-kasus yang melibatkan warganegaranya sendiri, dan luput dari pengamatan dan kritisisme asing." 49

Tanzimat berarti reorganisai atau menyusun kembali. Tanzimat merupakan pengganti dari kebijakan sebelumnya, Nizam-i-jadid yang diintrodusir oleh Salimm III, dengan konteks yang lebih luas. Kebijakan ini merupakan upaya elit Turki Usmani untuk memadukan tradisi sendiri dengan tradisi Barat dimana konsep nasionalisme dan demokrasi dipertimbangkan untuk menguatkan tata kelola negara. Tapi kebijakan ini alih-alih memberi memberi ruang implementasi toleransi supaya menebar rahmat Islam, yang terjadi munculnya kesulitan bersatunya semua warga yang berbeda agama teruma dengan Kristen. Peperangan, kesadaran dan protes warganya sendiri memperlambat implementasi kebijakan Tazimat. Walaupun memberi keuntungan ekonomi bagi Kristen, tapi tidak signifikan. Di sisi lain negara juga dirugikan baik ekonomi maupun secara politik, karena warganya mulai

\footnotetext{
${ }^{48}$ Iqbal. 2005. Islamic Toleration \& Justice: Non-Muslim Under Muslim Rule. Pp. 174-7

${ }^{49}$ Iqbal. 2005. Islamic Toleration \& Justice: Non-Muslim Under Muslim Rule. Pp.177-80
} 
protes. Singkatnya kebijakan Tanzimat tidak berhasil memunculkan pemenuhan hak dan tanggungjawab secara adil di antara warganya. ${ }^{50}$

Di tengah kekurangan praktek toleransi yang ada karena kebijakankebijakan seperti di atas, beberapa contoh ada baiknya dibagi di sini. Sultan Muhammad II (1451-1481) setelah mengalahkan Konstantinopel memastikan Gereja Ortodok Yunani tetap bisa berfungsi seperti sebelumnya. Dia melarang penganiayayaan kepada orang Kristen dan memberi hak privileges kepada pimpinan gereja dan jajarannya. Dia memulihkan cara lama penghasil gereja dan menambahnya dengan bantuan yang diambil dari keuangan negara. Dia bahkan menghadiahkan kepada pimpinan gereja dan jajarannya dana sebear 1000 ashrafis, kuda terlatih, dan membolehkan dalam upacara keagamaan mereka untuk melewati kota. Pada dasarnya "negara Turki Usmani terlahir diperbatasan antara Islam dan Kristen. Dengan demikian keberadaannya terletak antara kekuasaan Muslim dan Kekuasaan Kristen, dan beberapa faktor lainnya, keadaan ingin sangat rentan untu terpacu untuk perang. Sufi terkenal, Jalal al-Din Rumi (1207-1273) dari Konya, Turki, adalah dianggap orang pertama yang mempelajari buku-buku Yunani dan biographi intelektual mereka, serta sultan lebih dari sekali memanggil arsitek-arsitek Yunani untuk mendekorasi mesjid dan kapal laut mereka." 51

Contoh lainnya ada cerita antara Sultan Salim I (1512-1520) dengan Syekh Jamali Effendi, Kepala Mufti kala itu, mengenai apakah menaklukan sebuah negara lebih baik dari pada mengajak suatu masyarakat masuk Islam. Syekh Jamali memilih mengajak masyarakat untuk masuk Islam. Tapi sultan menerjemahkan dengan menyuruh seleuruh warga non-Muslim untuk dibunuh. mendengar titah sultan Syekh Jamali bergegas menghadap sultan dan menjelaskan bahwa yang dimaksud dengan mengajak masyarakat nonMuslim masuk Islam adalah dengan cara damai dan tidak dengan membunuh non-Muslim. Dia menganjurkan kepada sultan untuk mengirim da'i untuk melakukan tigas itu. Dan ajakan tersebut hanya dilakukan tanpa paksaan dan suapan. Paksaan apapun dalam berdakwah tidak akan sesuai denga semangat al-Qur'an. Mendengar penjelasan syekh, sultan kemudian menarik kembali perintahnya dan mengajak masuk Islam secara paksa tidak disarankan. Sultan menjaga toleransi tidak hanya dalam hal agama tapi juga budaya.

\footnotetext{
${ }^{50}$ Iqbal. 2005. Islamic Toleration \& Justice: Non-Muslim Under Muslim Rule. Pp. 180-4

${ }^{51}$ Iqbal. 2005. Islamic Toleration \& Justice: Non-Muslim Under Muslim Rule. Pp. 164-5
} 
Anak-anak Devshirme pun tidak dipaksa untuk masuk Islam. Mengutip Lewis, Iqbal merujuk, "kebanyakan orang-orang Rumelia tidak berasimilasi dengan Islam dan bahasa Turki. Banyak masayarakat tetap beragama Kristen, asing terhadap bahasa, budaya agama, diluar horizon buadaya orang-orang Turki." 52

Toleransi di zaman kesultanan Safawi adalah contoh toleransi di kalangan internal ummat Islam. Masyarakat Muslim Safawi memiliki latar belakang Islam sunni dan Syi'i dan latar belakang keagamaan sufistik. Pada awalnya mayoritas masyarakat kesultanan Safawi adalah Sunni, tapi karena gerakan Syi'i yang cukup kencang didukung dengan kekuatan negara sebagai paham keagamaan resmi terjadi transformasi paham dan situasi menjadi berbalik, komunitas Syi'ah menjadi mayoritas. Gerakan transformasi ini puncaknya terjadi pada masa Sultan Juneid dan Haidar. ${ }^{53}$ Hubungan kedua belah pihak tentunya tidak hanya diwarnai dengan perselihan dan berebut pengaruh dan pengikut, tapi juga sebaliknya diwarnai dengan hubungan yang saling menghormati dan menguntungkan. Ada situasi obyektif kenapa hubungan Syi'ah dan Sunni dimungkinkan terjadi. Pertama, masyarakat Muslim Sunni khususnya di Asia Barat pada saat itu sekitar 1300an M sedang menghadapi serangan bangsa Mongol yang bersemangat untuk meluluhlantakkan tidak hanya Muslim tapi, tempat dan peradabannya. Di tengah perbedaan yang ada, Syi'ah adalah Muslim juga, dan Muslim adalah saudara seagama terlepas perbedaan yang ada. Walaupun kemudian banyak masyarakat Muslim yang menganut paham Syi'ah, tampaknya secara sosiologis, hal tersebut menjadi pilihan rasional banyak masyarakat Muslim Sunni di tengah euphoria sebagian masyarakat dan juga negara yang berpaham Syi'i untuk mensyi'arkan paha Sy'iah. Di sisi lain, sufisme menjadi jembatan bagi ke dua kelompok berinteraksi secara harmonis. Walaupun pada faktanya tradisi sufisme yang didukung dengan tradisi filosofis kaum syi'ah menjadi daya tarik yang kuat sehingga kemudian lebih mendukung transformasi paham Syi'ah di kesultanan Safawi dari pada menjaga keutauhan dua komunitas. Nasr menambahkan bahwa "peran-peran perkumpulan-perkumpulan Kubrawiyyah, Nurbaksyiyyah dan Nikmatullahiyyahyi' menunjukkan telaah yang seksama di dalam sinaran hubungan mereka denga perkembangan akhir Syi'isme di Persia melalui

\footnotetext{
${ }^{52}$ Iqbal. 2005. Islamic Toleration \& Justice: Non-Muslim Under Muslim Rule. P.165

${ }^{53}$ Seyyed Hossein Nasr. 1987, 1994 terjemahamn Bahasa Indonesia. Islam Tradisi di tengah kancah Dunia Modern. Bandung: Penerbit Pustaka, P. 56-9
} 
suatu dinasti yang berasal dari sufi." Ditambah lagi komunitas Syi'ah dan negara banyak mengundang ulama Syi'ah untuk datang ke Persia. Persentuhan intelektuan dan interaksi sosial mereka terekam dalam misalnya dalam buku-buku biography, seperti Lu'lu'at al-bahrayn dan Amal al-'Amil. Mullah-mullah yang sederhana sampai figur sebesar Baha'uddin al-'Amili, Sayyid Nikmatullah al-Jazai'i berinterkasi, saling menuntut ilmu dan tumbuh menjadi otoritas yang disegani. ${ }^{54}$

Toleransi di kesultanan Mughal mempunyai nuansa baru dimana masyarakat di daerah kekuasaan ini beragama umumnya Hindu dan Budha. Iqbal menulis enam poin mengenai toleransi di kesultanan India. Pertama, pemimpim besar di kesultanan menunjukan sikap toleransi yang tinggi. NonMulsim mendapat perlndungan dan kebebasan untuk beribadah. Kedua, ada memang kejadian-kejadian intoleran, tapi hal tersebut tidak bisa dianggap mewakili potrat toleransi secara keseluruhan Muslim di India. Ketiga, penakluk Muslim tidak lama setelak penguasaan daerah baru di India melakukan restorasi dan keamanan publik dengan cara memulihkan interaksi sosial yang ada dan menghormati tradisi dan peraktek keagamaan yang ada. Keempat, kesultanan memperlakukan secara adil terhadap warganya tanpa melihat agama dalam masalah politik dengan fokus menjaga integrasi territorial negara. Kelima, setelah restorasi keadaan stabil paska penaklukan, penguasa Muslim memperlihatkan sikap menjaga perasaan warga barunya dengan berusaha memanfaatkan kekayaan dan pendapatan negara untuk kemakmuran dan kepentingan warga barunya tersebut. Misalnya, Sultan Alamgir lebih memilih memanfaatkan kekayaan negara yang ada buat kebaikan warganya dari pada buat upeti yang dikirim ke Mekkah. Keenam, kesultanan tidak membentuk unit tersendiri untuk mengkonversi masyarakat menjadi Muslim. ${ }^{55}$

Muhammah Ibn Qasim, komandan yang memasuki India pertama awal abah $8 \mathrm{M}$, diingatkan oleh Gubernur Dinasti bani Umayyah provinsi bagian Tumur, setelah menguatkan benteng pertahanan dan memnuhi kebutuhan tentara, ibn qosim diminta untuk memperhatikan kesejahtraan masyarakat dan pekerjaan-pekerjaan untuk fasiltas publik, karena kesejahtraan dan kebahagian mereka, pedagan dan pekerja yang akan membuat negara sejahtera. Secara umum bersikap baiklah terhadap mereka yang ditaklukan.

\footnotetext{
${ }^{54}$ Nasr. 1987, 1994 terjemahamn Bahasa Indonesia. Islam Tradisi di tengah kancah Dunia Modern. Pp. 55-6

${ }^{55}$ Iqbal. 2005. Islamic Toleration \& Justice: Non-Muslim Under Muslim Rule. P. 189
} 
Gubernur juga mengingatkan ibn Qasim untuk memperhatikan dari masyarakat lokal yang ingin mempunyai tanah atau tata kelola sendiri dan menerima usulan mereka dengan memberi mereka perlindungan keamanan dan maaf. Gubernur juga memesan kepada ibn Qasim pada hari raja Dahir kalah, agar memberikan perlindungan kepada yang tua, yang terpandang, membebaskan pengacau setelah diselidiki secara seksama, dan memberikan kebebasan beragama kepada kaum Hindu Brahmana setelah mereka memberikan loyalitasnya kepada Islam. Tidak ada pemaksaan dalam beragama, mereka yang tetap dalam agama mereka diberi kebebasan. ${ }^{56}$

Sultan Mahmud dari Ghazni (1021) menarik disinggung disini. Menurut penuturan Dr. Prashad, ditutip Iqbal, "Mahmud mempunyai banyak talenta. Dia mengatur rakyatnya dengan adil, melindungi perdagangan, dan menjaga ketertiban umum sehingga kapilah-kapilah bisa berlaulalang dengan aman antara Khorasan dan Lahore.Gubernur provinsi dikontrol dan tidak dizinkan untuk melakukan penindasan rakyat." Sultan sangat menghormati ummat Hindu, tidak membedakan antaraHindu atau Muslim. Dia menindak tindak kriminalitas dan pemberonakkan yang dilakukan baik oleh ummat Hindu atau Ummat Islam itu sendiri. Bahkan Sultan dan kerajaan Hindu setempat seperti Raja Jaipal berselisih, Sultan memaafkan kerajaan tersebut setelah diredakkan. ${ }^{57}$

Di masa hidupnya, pendiri kesultanan Mughal di India, Zahir al-Din Babar yang memimpin anatara 1526-1530, memberi nasehat kepada anaknya Humayun. Humayun diminta untuk menjaga kebersihan hati, bersikap adil ke setiap kelompok masyarakat, dan tidak menghancurkan tempat ibadah seperti candi. Perbedaan kelompok dalam internal agama seperti Sunni dan Syi'ah jangan diperhatikan, karena akan melehkan Islam itu sendiri. Humayun diminta untuk tidak bias dalam permasalah keagamaan dengan cara memperhatikan perasaan setiap ummat beragama, mengatur mereka secara adil, tidak menghancurkan tempat ibadah, dan memperhatikan kenyamanandan penerimaan rakyat. ${ }^{58}$

Perlu dicatat dari kerjaan Mughal adalah Raja Akbar mengeluarkan kebijakan tolerans universal, yang tidak membedakan etnis dan agama. Akbar memandang semua warga yang berada dalam wilayah kekuasaannya

\footnotetext{
${ }^{56}$ Iqbal. 2005. Islamic Toleration \& Justice: Non-Muslim Under Muslim Rule. P. 190-1

${ }^{57}$ Iqbal. 2005. Islamic Toleration \& Justice: Non-Muslim Under Muslim Rule. Pp. 194-6

${ }^{58}$ Iqbal. 2005. Islamic Toleration \& Justice: Non-Muslim Under Muslim Rule. Pp. 203-4
} 
dipandang sama. ${ }^{59}$ Nama lengkanya adalah Jalal al-Din Akbar (1556-1605 M). Akbar nampaknya meneruskan gagasan dasar toleransi Shear Shah Suri (1540-1545 M). Prinsip toleransi Suri seperti dijelaskan sendiri adalah "Esesnsi perlindungan agung terdiri dari perlindungan hidup dan harta benda rakyat. Penguasa harus memegang prinsip keadilan dan equalitas dalam semua urusan denga rakyatnya dari semua kelas dan negara mesti menyedian jajaran yang bisa mencegah terjadinya kekerasan atau diskriminasi di antara rakyatnya." ${ }^{\circ 0}$ Namun konsepsi toleransi Akbar lebih jauh dari Suri, dia mengusulkan Din-illahi -Divine faith, suatu panthaieme eklektik, yang terdiri dari elemen-elemen dari berragam agama. Walaupun pemikiran Akbar dikritik karena dapat dianggap sebagai upaya mengganti tradisi awal Islam, pemikiran Akbar sangatlah melampaui zamannya. Tidak heran kalau tawaran konsepsi toleransi universal banyak mendapat tantangan. ${ }^{61}$

\section{Belajar dari Sejarah: Memupuk Nilai dan Tradisi Toleransi di Indonesia}

Dalam beberapa dekade belakangan ini, tradisi toleransi di Indonesia dicederai oleh munculnya sejumlah kasus intoleransi seperti kejadian intoleransi di Poso, Ambon, Bekasi, Tasikmalaya, dan beberapa tempat lainnya. Banyak faktor yang menyebabkan terjadinya tindakan intoleran tersebut mulai dari salah paham, perubahan sosio-kultural, sosial ekonomi, politik, sentiment ethnik, sampai sentiment keagamaan. Peristiwa-peristiwa intoleransi tersebut sebenarnya tidak perlu terjadi kalau melihat apa yang dimiliki oleh bangsa Indonesia tentang modal nilai dan tradisi toleransi. Dalam hal ini ummat Islam di Indonesia sejatinya dapat mengambil peran yang lebih konstruktif karena modal sosial dan budaya toleransi yang dimilikinya dalam bentuk penyebaran Islam dan hidup bersama yang damai. Lebih jauh lagi sebenarnya seperti dijelaskan di atas, ummat Islam di Indonesia patut berbangga hati dan bersyukur karena memiliki tidak hanya sumber ajaran agama yang toleran dan moderat, tapi juga preseden historis yang kaya sekali. Preseden historis adalah nyata dan dapat difungsikan sebagai modal sosial dan representasi simbolik yang kuat.

\footnotetext{
${ }^{59}$ Yatim. 2001. Sejarah Peradaban Islam. P. 149

${ }^{60}$ Iqbal. 2005. Islamic Toleration \& Justice: Non-Muslim Under Muslim Rule. P. 205.

${ }^{61}$ Iqbal. 2005. Islamic Toleration \& Justice: Non-Muslim Under Muslim Rule. Pp. 207-13
} 


\section{a. Preseden Toleransi dalam Peradaban Islam sebagai Modal Sosial}

Peradaban Islam menginformasikan bahwa beberapa nilai dan sistem dari dimensi toleransi bertemu antara inspirasi normatif ajaran Islam dengan praktek historis dilapangan, seperti menghormati pelaksanaan agama, melindungi hak penganut agama lain, menghargai dan melindungi yang lemah, dan kesediaan untuk hidup berdampingan. Semua dimensi toleransi tersebut merupakan modal soial atau kekuatan bersama dimana ummat Islam Indonesia dapat memanfaatkannya untuk memainkan peran mayoritas pemersatu dan pemerhati keharmonisan, dan tidak mudah emosional dan terpancing dengan hal-hal yang kurang produktif.

Memang, seperti disinggung di bagian pendahuluan bahwa toleransi sering terjadi dari keadaan dimana salah satu agensi berperan dominan sebagai subyek. Dalam konteks kontemporer sekarang dimana masyarakat Indonesia sudah jauh lebih terdidik daripada di zaman penjajahan dulu, agensi toleransi sebenarnya secara normatif dapat berperan lebih rasional lagi sehingga tidak mudah untuk salah paham, atau dimanfaatkan untuk kepentingan pihak-pihak tertentu.

Ketidakadilan sosial dan kurangnya antisipasi terhadap perubahan jumlah penduduk dan distribusinya di seluruh negeri adalah faktor umum yang mempengaruhi mutu dan praktek toleransi. Setiap individu dan keluarga memerlukan ruang memadai dan hidup layak untuk dapat secara utuh bertindak rasional dalam hidupnya. Apabila sebagian dari ruang dan kelayakan hidup itu terganggu, maka dengan sendirinya hal tersebut akan mengganggu kerukunan hidup berdampingan secara damai dengan anggota masyarakat lainnya. Dalam konteks seperti ini, yang diperlukan adalah solusi rasional akan masalah obyektif yang dihadapi. Negara merupakan agensi terdepan yang menanggung beban tanggunjawab untuk mengurai ketidakadilan dan ketidak-merataan distribusi penduduk dengan segala keniscayaan distribusi kesempatan dan fasilitas yang diperlukan. Masyarakat tentunya akan mengikuti kebijakan pemerintah sepanjang kebijakan dan program mereka menjunjung kepentingan bersama. Ummat Islam Indonesia dapat belajar dari peradabannya bahwa sejarah Islam menunjukkan pelajaran untuk tetap memelihara hak setiap warga walaupun kaum muslimin berkedudukan sebagai mayoritas dan penguasa.

Selanjutnya, ummat Islam Indonesia dapat belajar dari sejarah keberadaan mereka dengan lainnya di Indonesia atau dari sejarah peradaban 
Islam secara umum untuk memupuk dan meningkatkan nilai dan tradisi toleransinya. Salah satunya adalah bahwa ummat Islam termasuk ummat Islam Indonesia tidak memiliki hambatan teologis untuk bisa hidup secara berdampingan dengan penganut agama lain secara damai dan saling menghormati. Yang nama hidup berdampingan tentunya memerlukan penghormatan atas kekhasan yang dimiliki penganut agama masing-masing, dan ada wilayah dimana semuanya mesti bersedia untuk berbagi agar memungkingkan untuk hidup bersama dengan cara saling menghargai satu dengan lainya. Dalam hal ini ummat Islam Indonesia tidak mesti merasa khawatir karena kelapangan, penghormatan, dan perlindungan mereka terhadap warga negara lainnya memupuk modal sosial positif toleransi dan berkontribusi atas kemarmonisan dan kesatuan negara Indonesia.

\section{b. Representasi Simbolik Peran Ummat Islam}

Peran ummat Islam yang perlu mendapat perhatian lain adalah bagaimana mereka memerankan peran simbolik mewakili warga Indonesia sebagai warga yang toleran. Sebenarnya inilah kesempatan terbesar ummat Islam Indonesia untuk memainkan perannya sebagai warga negara mayoritas Muslim terbesar di dunia. Kenyataan bahwa jumlah ummat Islam Indonesia merupakan jumlah penduduk terbesar merupakan pemenuhan syarat mendasar terwujudnya toleransi. Hanya saja pemenuhan syarat tersebut mesti jalin berkelindan dengan pemenuhan syarat penting lainnya, yaitu rasionalitas atau obyektivitas. Rasionalitas atau obyektivitas di sini maksudnya adalah penggunaan pertimbangan-pertimbangan obyektif untuk hidup bersama secara layak dan sustainable. Masyarakat apalagi masyarakat Indonesia yang plural memerlukan hidup yang layak dan sustainable. Tidak terpenuhinya syarat-syarat tersebut dapat membuka jalan bagi anggotanya untuk melakukan tindakan anarkis yang merusak modal sosial toleransi dan kehidupan harmonis baik sesama manusia maupun dengan alam sekitar. Syarat-syarat obyektif ini tentu menjadi tanggungjawab bersama khususnya pemerintah karena merekalah yang memegang kebijakan perencanaan dan pelaksanaan program kegiatan dan pengaturan sumber dana terbesarnya.

Beberapa peran simbolik ideal yang dapat dimainkan oleh ummat Islam Indonesia adalah peran politik demokratis, peran good and transparent government, peran toleransi beragama, dan peran peaceful and harmonious co-existence. Transformasi politi pada tahun 1998 dari tatanan politik Orde 
Baru ketatanan politik Orde Reformasi yang mengusung lebih banyak nilai dan sistem demokrasi dengan pengalaman dua dekade menempatkan Indonesia sebagai negara berkembang dengan mayoritas penduduk muslim sebagai laboratorium demokrasi kontemporer par excellence, menginspirasi banyak negara-negara Islam lainnya. Kekuatan reformasi demokrasi ini yang menjadi sandaran kokoh dalam mensikapi berbagai gangguan yang ada termasuk gangguan intoleransi. Memang terdapat ekses chaos of information sebagai konsekwensi dari kebebasan berpendapat dan berekspresi, tapi kesemuanya secara umum dapat dilalui dalam bingkai-bingai demokrasi sehingga tidak terjadi eskalasi yang tidak terkontrol lebih jauh. Kemampuan pemerintah dan kedewasaan warga negara termasuk ummat Islam di dalamnya semakin teruji dari waktu ke waktu.

Pemerintah Indonesia yang tentunya mayoritas dipegang oleh warga negara yang beragama Islam dalam dua decade terakhir ini juga berhasil menerapkan suatu sistem dan mekanisme kontrol tindakan korupsi yang semakin baik. Perangkat kontrol dan tindakan pengamanan yang ada -Irjen, BPK, dan KPK ditengah kelemahan yang masih dimilikinya menunjukkan kinerja yang positif sehingga pelan tapi pasti citra good and accountable government berada dalam grafik yang positif.

Terakhir, peran toleransi beragama, dan peran peaceful and harmonious co-existence dari bangsa Indonesia dan khususnya warga negara beragama Islam semakin baik dan dewasa. Hal ini ditunjukkan dengan kemampuan ummat Islam dalam mengaktualisasikan kebebasan berpendapat dan berekpressi yang terukur. Memang secara internal, ummat Islam di banyak geografi termasuk di Indonesia menunjukkan sikap-sikap sensitif terutama kalau sudah masuk ke wilayah sara.Yang menarik dari perkembangan sekarang adalah terdapatnya kemampuan mereka untuk memenej rasa sensitivitas mereka dalam koredor hukum, dan batas-batas kepatutan yang ada. Dalam kasus "penistaan agama" yang melibatkan mantan Gubernur DKI Jakarta Basuki Tjahaya Purnama yang dikenal dengan Ahok, misalnya, walaupun ummat Islam berekasi sangat keras dan massive, akan tetapa mereka tidak hanya berhasil menjaga ketertiban dan kedamaian yang diperlukan, tapi juga berhasil menunjukkan demonstrasi dalam skala besar tanpa meninggal sampah dan perusakan fasilitas publik yang tidak perlu. Poin ini sangatlah penting karena tidak banyak pihak lain termasuk ummat Islam di geografi lain yang memiliki sensitivitas agama yang tinggi 
mampu memenej kekuatan besar tanpa menimbulkan ekses destruktif. Dengan kata lain, ummat Islam Indonesia berhasil memainkan peran simbolik sebagai bagian warga dunia menjunjung nilai-nilai sivilitas. Tradisi toleransi di Indonesia yang dippupuk dengan tradasi yang sama dalam peradaban Islam dapat menjadi salah satu dimensi outlook Islam sebagai agama rahmatan lil ‘Alamin.

\section{Penutup}

Toleransi dalam peradaban Islam sampai menjelang periode modern menginformasikan berbagai pengalaman berharga bagaiamana ummat Islam dan lebih khusus penguasa Islam memperlakukan non-Muslim. Preskripsi normatif dari al-Qur'an dan contoh awal dari praktek Rasulullah dan para sahabat menjadi preseden dan referensi bagi ummat Islam setelahnya. Adalah fakta sejarah dan juga pengalaman mengagumkan kalau peradaban Islam mempunyai pengalaman praktek toleransi lebih awal dari lainnya, misalnya negara-negara Barat. Dalam lintasan sejarah, praktek toleransi ummat Isam menjadi kekuatan peradaban tersendiri yang memiliki kekuatan dan daya yang sulit ditolak seperti cepatnya proses penerimaan rakyat yang ditaklukan paska penaklukan, merasa aman untuk beribadah menurut keimanan mereka, terlindunginya orang tua, anak-anak, perempuan dan rohaniawan dan bebasnya beraktivitas sosial lainnya, dan bahkan menjadi harapan bagi suatu komunitas atau rakyat untuk terbebas dari penguasa mereka yang menindas. Hal ini ditunjang juga dengan kenyataan tempat lahir dan berkembangkan Islam awal mempunyai konteks lingkungan eksternalnya yang lebih toleran, yaitu peradaban Sasanian, daripada konteks yang mengitarinya lainnya seperti Bizantium. Pertemuan antara preskripsi normatif ideal dengan konteks dimana benih-benih toleransi disemaikan untuk pertama kali, memudahkan persemaian lainnya di tempat dan waktu yang beragam.

Pengalaman praktek toleransi ummat Islam bersinggungan dengan ummat besar lainnya sampai zaman pra-modern, secara agama mulai dari Kristen, Zoroaster, Yahudi, Hindu dan Budha, secara bangsa mulai dari bagsa Arab dimana nabi dan ummat awal menerima Islam, Persia, India, Mongol, Turki Umani, Seljuk, Ilkan, Melayu, Cina, Afrika, dan bangsabangsa Barat, dan secara geografis, Timur Tengah, Afrika, Asia terutama Tengah dan Tenggara, Cina dan Eropa khususnya Spanyol dan negara- 
negara Balkan. Menarik di simak pada sisi prinsip toleransi dan kelompok yang diberi toleransi. Dari sisi prinsip, keadilan atau imparsialitas diterapkan sering dengan memberi privileges dan kasih sayang. Keadilan ditegakkan dalam arti tidak membedakan agama, etnik dan golongan selalu ditransmisikan dari satu kekuasaan ke kuasaan Islam lainnya. Pada saat yang sama, penerapan keadilan diiringi denga rasa kasih sayang dalam bentuk pengutamaan, previlege bahkan rekapitulasi, dengan maksud awal sebagai implementasi Islam sebagai agama rahmat bagi semesta alam. Pada satu sisi, implementasi aspek ini terjadi dalam bentuk tidak membedak-bedakan antara ummat Islam dalan lainnya pada sistuasi hubungan seimbang antara pembayaran jizyah yang ditekankan tidak memberatkan dan dibebankan secara proporsional dengan beberapa pengecualian, dengan perlindungan dan penjaminan well being (kehidupan yang layak) bagi semua, khususnya bagi ahli dhimmi. Di sisi lain, toleransi terefleksi dalam berbagai kegiatan budaya, mulai dari kegiatan ilmiah sampai kegiatan politik, dimana bentuk negara pada fakta sejarah menunjukkan keragaman, mulai dari kekhalifahan, kerajaan, kesultanan di zaman pra-modern dan sistem pemerintahan negara bangsa, demokrasi dll., di zaman modern. Lebih jauh, pernah terjadi praktek toleransi universal seperti yang diusulkan sultan Akbar yang mencoba tidak membedakan agama dan bangsa atau kelompok pada level humanistik.

Peradaban toleransi dalam peradaban Islam sampai menjelang periode modern diwarnai oleh suatu nilai umum, yaitu relasi kuasa. Relasi kuasa tertanam secara laten baik di internal suatu kekuasaan (kerajaan/kekhalifahan/kesultanan/imperium/negara) tertentu atau antar dua atau lebih kelompok kekuasan. Tidak heran kalau ada benang merah kalau perdamaian, ketentraman dan seterusnya seperti kesejahteraan baru dapat ditumbuhsuburkan kalau kekuasaan tersebut sudah terbangun. Yang menarik banyak dari praktek relasi kuasa dalam konteks implementasi toleransi dalam peradaban Islam mengambil kebijakan "merangkul" dengan syarat yang tidak memberatkan dan bukan reconquista (pengembalian kembali wilayahwilayah dari tangan Muslim oleh pasukan Kristen Spanyol) ${ }^{62}$ yang tidak memberi pilihan tetap dalam keimanan lama tanpa harus pergi dari tempat yang telah menjadi "tanah airnya."

Tantangan bagi ummat Islam dalam konteks implementasi toleransi di zaman kontemporer datang dari dua arah, pertama dari luar, ummat Islam

${ }^{62}$ Nasr. 2003. Islam: Agama, Sejarah, dan Peradaban. P. 146 
menghadapi pencitraan yang negatif terutama paska kejadian 11 September 2001, pengeboman WTC dan kantor pusat FBI. Dan kedua secara internal, ummat Islam dihadapkan respon yang beragam terhadap modernitas ditengah arus globalisasi dan kemajuan teknologi komunikasi dengan ciri ada indikasi penguatan radikaslisme agama. Belajar dari peradaban Islam, sebenarnya ummat Islam khususnya ummat Islam Indonesia mempunyai bekal kuat untuk bisa menghadirkan kembali kualitas toleransi yang sempat membuat banyak pihak terkagum-kagum dari pihak "musuh" sekalipun. Bekal tersebut dapat digunakan baik dengan cara memanfaatkan preseden sejarah tersebut sebagai modal sosial untuk memupuk tradisi toleransi di tanah air, maupun untuk memainkan peran representasi simbolik Islam yang damai dan toleran bagi dunia. Bekal tersebut perlu dipelajari dan dengan belajar dari sejarah, mudah-mudahan peradaban toleransi Islam termasuk peradaban toleransi di Indonesia mampu berjaya kembali menghantarkan Islam sebagai agama rahmat bagi semesta alam.

Wallahu a'lam bi al-ṣowwab

\section{DAFTAR PUSTAKA}

Zoran Matevski, Ph.D., Associate professor, UDK: 316.72:2;271.2(497.7); 299.5. Religious Dialogue and Tolerance - Theoretical and Practical Experiences of Differences and Similarities. University of Ss. Cyril and Methodius, Skopje, Republic of Macedonia.Pp. 43-57.

Jonathan Benthall. 2005. Confessional Cousins and the Rest: The Structure of Islamic Toleration Anthropology Today, Vol. 21, No. 1, Policy and Islam (Feb., 2005), pp. 16-20.

Robert M. Hayden. Antagonistic Tolerance Competitive Sharing of Religious Sites in South Asia and the Balkans. Current Anthropology, Volume 43, Number 2, April 2002, Pp. 205-231.

Aaron Tyler. n.d. Tolerance as a Source of Peace: Gülen and the Islamic Conceptualization of Tolerance. Islam in the Age of Global Challenges. N.p. Conference Proceedings.

Jamsheed K. Choksy. 1987. Zoroastrians in Muslim Iran: Selected Problems of Coexistence and Interaction during the Early Medieval Period. Iranian Studies, Vol. 20, No. 1 (1987), pp. 17-30.

Muhammad Rasyid Ridha. 1987. Cet ke 2. Wahyu Ilahi Kepada Muhammad. Jakarta: Pustaka Jaya. 
Riaz Hasan. 2006. Keragaman Iman: Studi Komparatif Masyarakat Muslim. Jakarta: PT. RajaGrafindo Persada.

Ira M. Lapidus. 1988. A History of Islamic Society. Cambridge: Cambridge University Press.

Sayyed Hossein Nasr. 2003. Islam: Agama, Sejarah, dan Peradaban. Surabaya. Risalah Gusti.

Muhammad Iqbal. 2005. Islamic Toleration \& Justice: Non-Muslim Under Muslim Rule. New Delhi: Adam Publishers \& Distributors.

Badri Yatim. 2001. Sejarah Peradaban Islam; Dirasah Islamiyah II. Jakarta: Rajawali Press.

Komisi Nasional Mesir untuk UNESCO. 1986. Sumbangan Islam Kepada Ilmu Pengetahuan dan Kebudayaan. Bandung: Penerbit Pustaka.

Seyyed Hossein Nasr. 1987, 1994 terjemahamn Bahasa Indonesia. Islam Tradisi di tengah kancah Dunia Modern. Bandung: Penerbit Pustaka.

Resat Kasaba. 1988. The Ottoman Empire and the World Economy the Nineteenth Century. Albany: State University of New York.

Abdul Muqsith Ghazali. 2009. Argumen Pluralisme Agama: Membangun Toleransi Berbasis al-Qur'an. Depok: KataKita.

John L. Esposito dan Dalia Mogahed. 2008. Saatnya Muslim Bicara. Bandung: Mizan. 